*akls View/Frint Document Cover Sheet tow

This document was retrieved from the Boeing ISEARCH System.

Accession \#: D196054804

Document \#: SD-WM-ER-449

Title/Desc:

TANK 241TX118 HEADSPACE GAS \& VAPOR CHARACTERIZATION RESULTS FOR SAMPLES COLLECTED IN $9 / 1994 \& 12 / 1994$ 


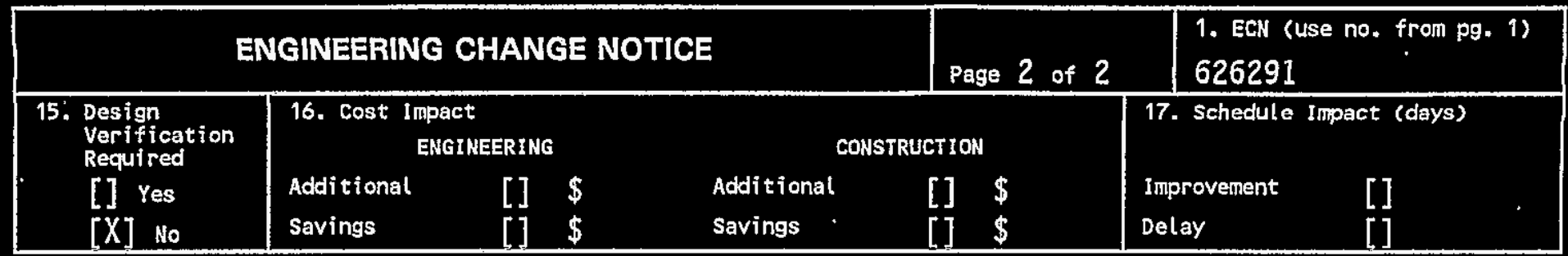

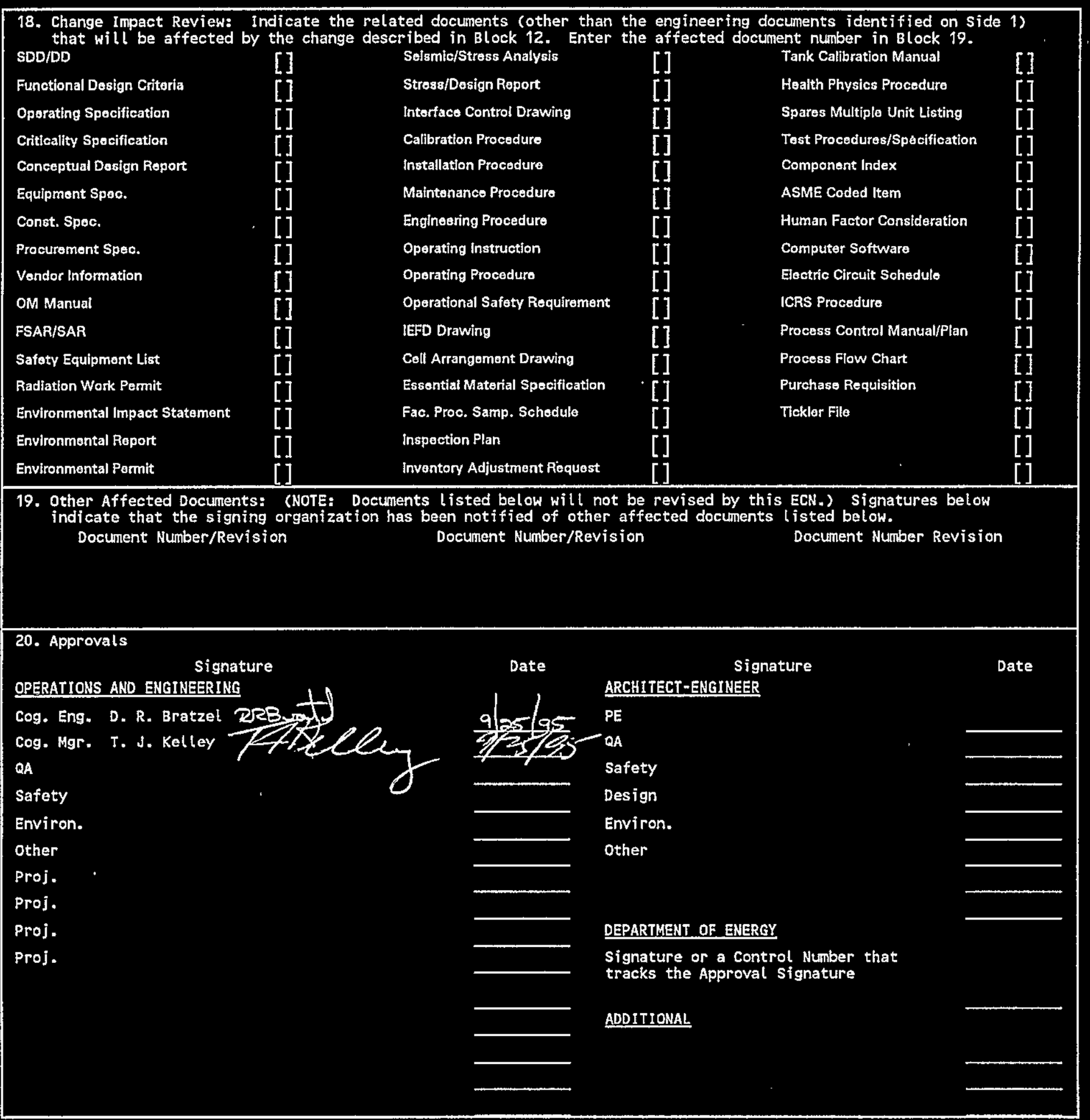




\section{RELEASE AUTHORIZATION}

\begin{tabular}{|ll|}
\hline Document Number: & WHC-SD-WM-ER-449, REV I \\
\hline Document Title: & $\begin{array}{l}\text { Tank 241-TX-118 Headspace Gas and Vapor } \\
\text { Characterization Results for Samples Collected in } \\
\text { September 1994 and December 1994 }\end{array}$ \\
\hline Release Date: & $9 / 27 / 95$ \\
\hline
\end{tabular}

This document was reviewed following the procedures described in WHC-CM-3-4 and is:

\section{APPROVED FOR PUBLIC RELEASE}

WHC Information Release Administration Specialist:
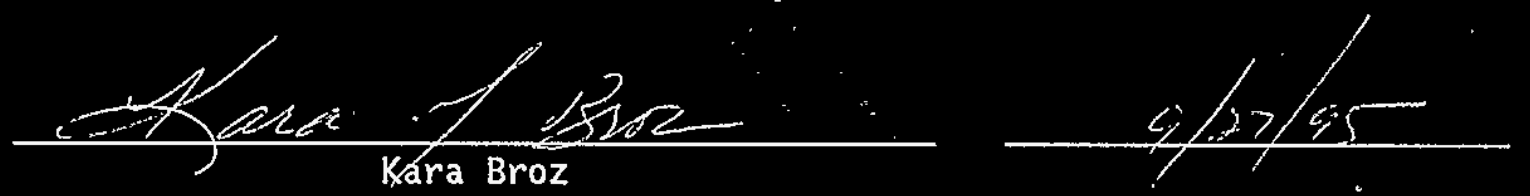

TRADEMARK DISCLAIMER. Reference here in to any specific commercial product, process, or service by trade name, trademark, manufacturer, or otherwise, does not necessarily constitute or imply its endorsement, recommendation, or favoring by the United States Government or any agency thereof or its contractors or subcontractors.

This report has been reproduced from the best available copy. Available in paper copy. Printed in the United States of America. To obtain copies of this report, contact:

Westinghouse Hanford Company - Document Control Services

P.0. Box 1970, Mailstop H6-08, Richland, WA 99352

Telephone: (509) 372-2420; Fax: (509) 376-4989 
, 


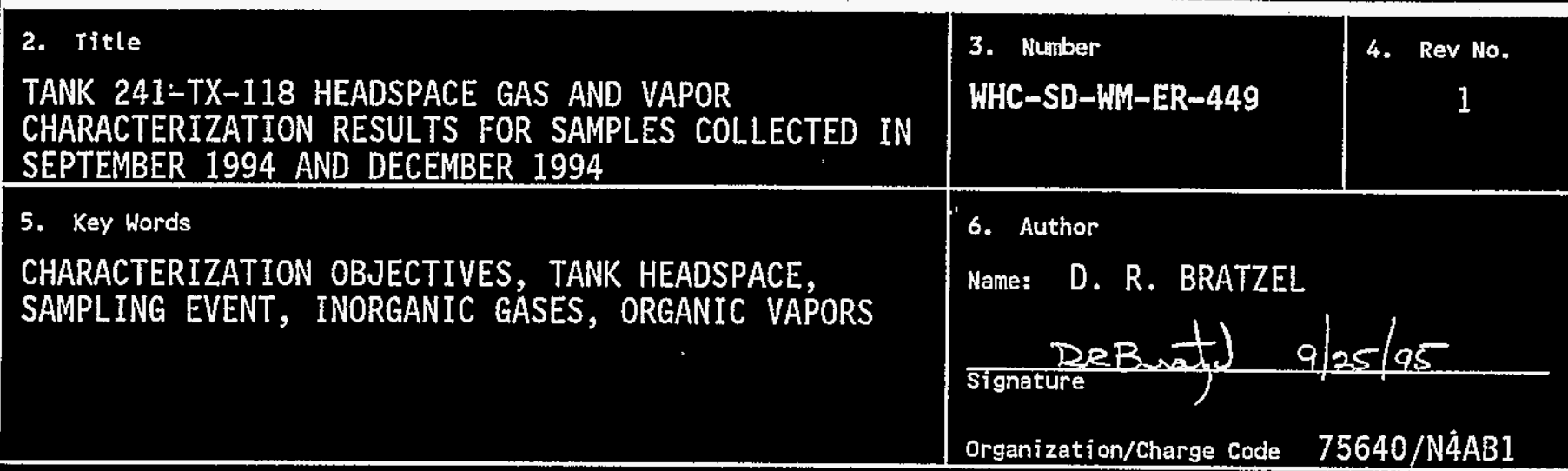

\section{Abstract}

Significant changes have been made to all of the original vapor characterization reports. This report documents specific headspace gas and vapor characterization results for all vapor sampling events to date. In addition, changes have been made to the original vapor reports to qualify the data based on quality assurance issues associated with the performing laboratories.

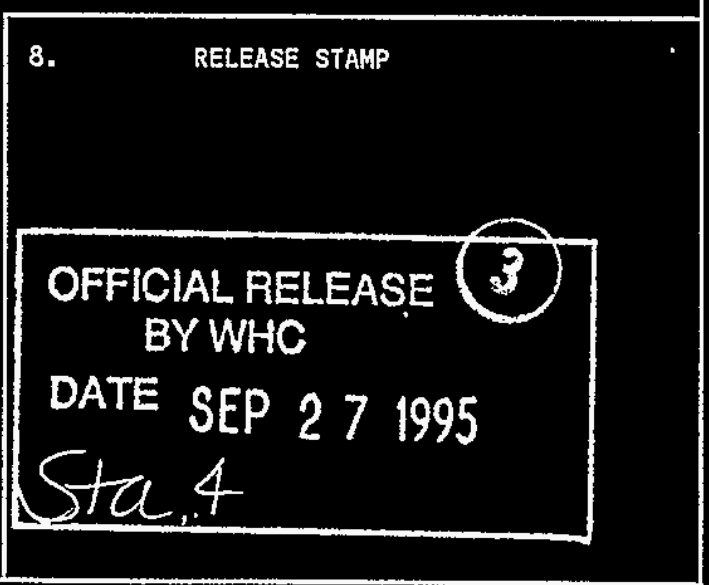




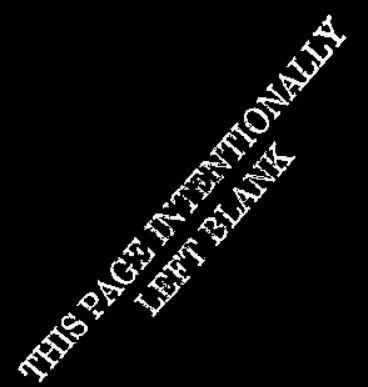




\begin{tabular}{|c|c|c|c|c|}
\hline & RECORD OF REVISION & \multicolumn{2}{|c|}{$\begin{array}{l}\text { (1) Document Number } \\
\text { WHC-SD-WM-ER-449 }\end{array}$} & Page 1 \\
\hline \multicolumn{5}{|c|}{$\begin{array}{l}\text { (2) Title } \\
\text { TANK 241-TX-118 HEADSPACE GAS AND VAPOR CHARACTERIZATION RESULTS FOR SAMPLES COLLECTED } \\
\text { IN SEPTEMBER } 1994 \text { AND DECEMBER } 1994\end{array}$} \\
\hline \multirow{2}{*}{ (3) Revision } & CHANGE CONTROL RECORD & \multirow{2}{*}{\multicolumn{3}{|c|}{ Authorized for Release }} \\
\hline & (4) Description of Change - Replace, Add, and Delete Pages & & & \\
\hline 0 & $\begin{array}{l}\text { (7) WHC-SD-WM-ER-449, REV. 0, EDT } 612341 \\
\text { May 31, 1995 }\end{array}$ & (5) Cog. Engr. & (6) Co & Mgr. \\
\hline 1 RS & $\begin{array}{l}\text { Complete revision and title change. ECN. } \\
626291\end{array}$ & $2 B$ tal & & \\
\hline & : & T & & 3 \\
\hline & & & & \\
\hline & & & & \\
\hline & & & & \\
\hline & & & & \\
\hline & 3 & & & \\
\hline & & & & \\
\hline • & & & & \\
\hline & & & & \\
\hline & & & & \\
\hline & & & & \\
\hline & & & & \\
\hline & & & & \\
\hline
\end{tabular}





\title{
Tank 241-TX-118 Headspace Gas and Vapor Characterization Results for Samples Collected in September 1994 and December 1994
}

\author{
J. L. Euckaby \\ Pacific Northwest Laboratories \\ D. R. Bratzel \\ Westinghouse Hanford Company
}

Date Published

September 1995 
4 


\section{WHC-SD-WM-ER-449 REV. 1}

\section{Contents}

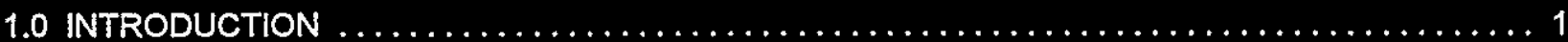

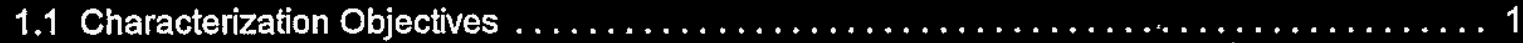

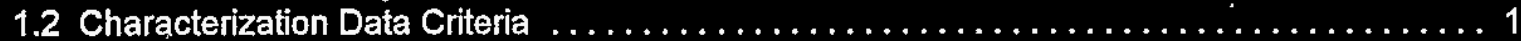

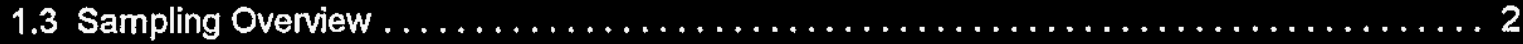

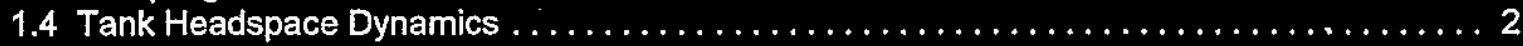

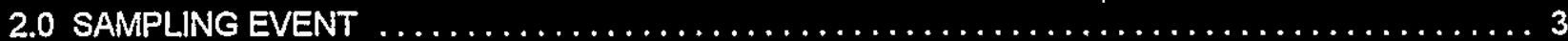

2.1 September 1994 In Situ Sampling Event . ............................. 3

2.2 December 1994 Vapor Sampling System Sampling Event $\ldots \ldots \ldots \ldots \ldots \ldots \ldots \ldots$

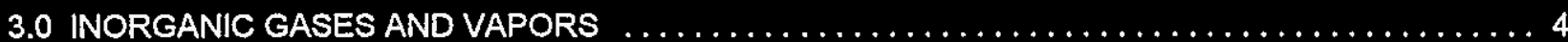

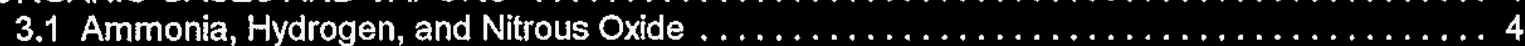

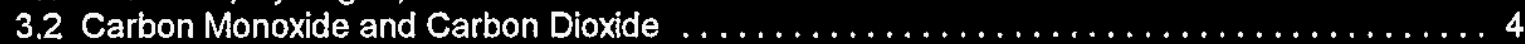

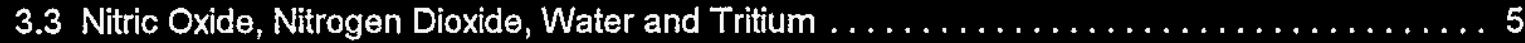

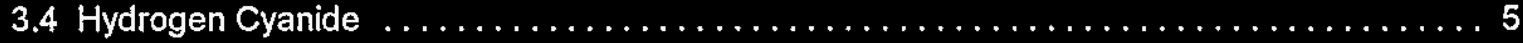

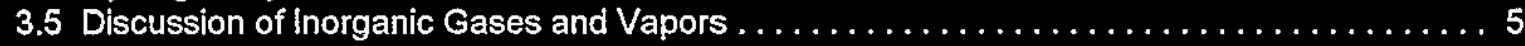

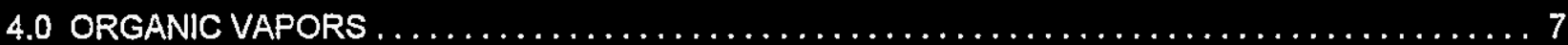

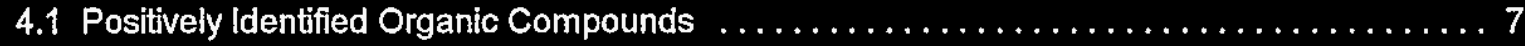

4.2 Tentatively Identified Organic Compounds $\ldots \ldots \ldots \ldots \ldots \ldots \ldots \ldots \ldots \ldots \ldots \ldots \ldots$

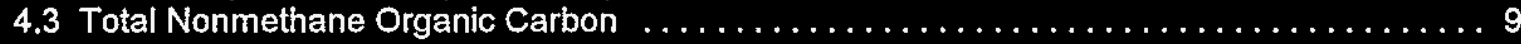

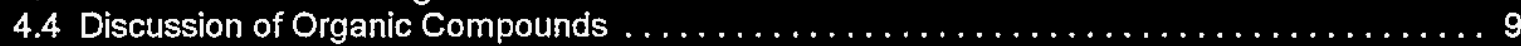

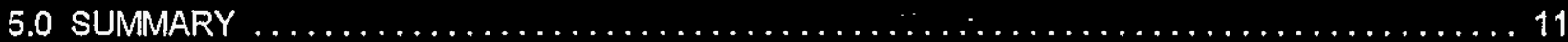

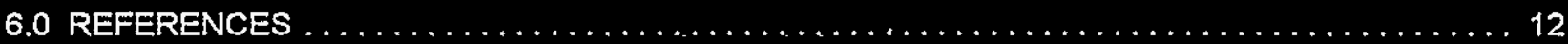

Acronyms and Abbreviations

$\begin{array}{ll}\text { CES } & \text { consensus exposure standard } \\ \text { EPA } & \text { Environmental Protection Agency } \\ \text { GC } & \text { gas chromatograph } \\ \text { GC/MS } & \text { gas chromatograph/mass spectrometer } \\ \text { LFL } & \text { lower flammability limit } \\ \text { MS } & \text { mass spectrometer } \\ \text { NFPA } & \text { National Fire Protection Association } \\ \text { NPH } & \text { normal parafinic hydrocarbon } \\ \text { OGIST } & \text { Oregon Graduate Institute of Science and Technology } \\ \text { ORNL } & \text { Oak Ridge National Laboratory } \\ \text { PNL } & \text { Pacific Northwest Laboratory } \\ \text { ppmv } & \text { parts per million by volume, 1 ppmv }=10^{-4} \text { vol\% } \\ \text { TNMOC } & \text { total nonmethane organic carbon } \\ \text { TST } & \text { triple sorbent trap } \\ \text { vol\% } & \text { percent by volume, } 1 \text { vol\% }=10,000 \text { ppmv } \\ \text { VSS } & \text { vapor sampling system } \\ \text { WHC } & \text { Westinghouse Hanford Company }\end{array}$


WHC-SD-WM-ER-449 REV. 1

\section{Acknowledgements}

The author wishes to thank Chris Simonen for her work verifying data and generating tables, and Shas Mattigod for his help with the construction and reviews of this document. 
WHC-SD-WM-ER-449 REV. 1

Tank 241-TX-118 Headspace Gas and Vapor Characterization Results

for Samples Collected in September 1994 and December 1994

\subsection{INTRODUCTION}

\subsection{Characterization Objectives}

Tank TX-118 headspace gas and vapor samples were collected and analyzed to help determine the potential risks of fugitive emissions to tank farm workers. The drivers and objectives of waste tank headspace sampling and analysis are discussed in Program Plan for the Resolution of Tank Vapor lssues (Osborne and Huckaby 1994). This report primarily discusses results from the December 1994 sampling event, but also inciudes selected results of the September 1994 sampling event. The tank TX-118 headspace was sampled in September 1994 in accordance with Safety Assessment for Gas Sampling All Ferrocyanide Tanks (Fariey 1991), and in December 1994 in accordance with Data Quality Objectives for Generic in-Tank Health and Safety lssue Resolution (Osborne et al. 1994).

\subsection{Characterization Data Criteria}

Data Quality Objectives for Generic In-Tank Health and Safety Issue Resolution describes parameters for data collection to ensure appropriate conclusions can be drawn from the data. Tank headspace characterization data was coilected to help in the evaluation of 1) headspace flammability, and 2) identification and quantification of compounds of toxicological concern.

Single Shell Tank Interim Operational Safety Requirements (Dougherty 1995) specifies that combustible constituents in tank headspaces be maintained below $25 \%$ of the lower flammability limit (LFL). This essentially agrees with National Fire Protection Association requirements that combustible concentrations be maintained at or below $25 \%$ of the LFL (NFPA 1992). Current governing operating specifications for Watchilist tanks, such as tank TX-118, specify that combustible constituents be maintained at or below $20 \%$ 'of the LFL (WHC 1995a).

Headspace characterization data are used by Westinghouse Hanford Company (WHC) Tank Waste Remediation Systems Industrial Hygiene as source term data in the industrial hygiene strategy to protect workers from tank fugitive emissions. Because selection of worker protective equipment must be based on industrial hygiene monitoring of the work place and not on source term data (29 CFR 1910.120), tank headspace characterization data can not be used for this purpose. Furthermore, because there are mechanisms by which headspace constituents can be either diluted or concentrated as they are released to the atmosphere, the headspace characterization data should not be considered to be representative of emissions at the point of emission.

These statements notwithstanding, the data quality objectives document specifies that the industrial hygiene group be advised if constituents with toxicological properties exceed $50 \%$ of the appropriate consensus exposure standard (CES) for non-carcinogens, or $10 \%$ of the appropriate CES for carcinogens. A CES is defined as the most stringent of known regulatory or recommended toxicological values for the workplace (Osborne et al. 1994). 
WHC-SD-WM-ER-449 REV. 1

\subsection{Sampling Overview}

Tank TX-118 was vapor sampled in September 1994 using the in situ sampling (ISS) method, and again in December 1994 using the more robust vapor sampling system (VSS) method. Because the ISS sample volume flow measurement used during the September 1994 event was inherently less accurate than that of the VSS, the sorbent trap samples from the ISS event are not considered to be equivalent to those from the VSS sampling event (Huckaby et al. 1995). Furthermore, there are other discrepancies between results from the ISS and VSS methods that are not understood (Huckaby 1994a), and until the ISS method has been validated and the discrepancies resolved, results from early ISS events should be considered suspect.

Nevertheless, a brief description of the ISS event and hydrogen cyanide sampling results from the September 1994 ISS event are presented below, because this analyte was not sampled for during the VSS event. Huckaby et al. (1995) describe the bases for using the ISS method for hydrogen cyanide, and why it was not sampled for during the VSS event. Also, samples from the September 1994 ISS event were analyzed for total nonmethane organic carbon (TNMOC) by Oregon Graduate Institute of Science and Technology (OGIST), and these results are presented below because this anaiysis was not performed on samples from the December 1994 VSS sampling event. All other results presented here are from the December 1994 VSS sampling event.

Samples collected are thought to have been representative of the tank headispace when the tank was sampled (Meacham et al. 1995), and sample analyses were designed to provide a reasonably accurate and complete characterization of the significant headspace constituents. No assessment has been made of how the tank TX-118 headspace composition changes with time, though studies of tank C-103 suggest that composition changes probably occur very slowly in passively ventilated tanks, such as tank BY-103 (Huckaby and Story 1994).

\subsection{Tank Headspace Dynamics}

Tank TX-118 is the third tank in a 3-tank cascade with tanks TX-116 and TX-117. It is connected to tank TX-117 via a 7.4-cm (2.9-in.) inside diameter, 7.6-m (25-ft) long underground cascade line. Tanks TX-116 and $T X-117$ are connected by a similar line. Since these cascade lines connect the headspaces of these tanks, gases and vapors originating from the wastes in tank TX-116 or TX-117 may be transferred to tank TX-118 (unless the cascade lines are obstructed). At this time, however, no headspace characterization data are available for either tanks TX-116 or TX-117 to assess their potential effect on tank TX-118.

The cascade of tanks TX-116, TX-117, and TX-118 is passively ventilated, which means that the tanks are allowed to exhale air, waste gases, and vapors as the barometric pressure falls, and inhale ambient air as the barometric pressure rises. Each of these tanks has its own filtered breather riser. Barometric pressure typically rises and falls on a diurnal cycle, producing an average daily exchange of air equal to about $0.46 \%$ of each tank headspace (Huckaby 1994b). Changes in the concentrations of tank headspace constituents due to barometric pressure changes are consequently very slow. 
WHC-SD-WM-ER-449 REV. 1

\subsection{SAMPLING EVENT}

\subsection{September 1994 In Situ Sampling Event}

Tank TX-118 was sampled using ISS methods on September 7, 1994 by WHC Sampling and Mobile Laboratories. This sampling was conducted to satisfy requirements of Safety Assessment for Gas Sampling All Ferrocyanide Tanks (Farley 1991). Samples for hydrogen cyanide were collected from a point approximately $7.9 \mathrm{~m}$ below the top of the fiange on riser $9 A$, between 11:15 a.m. and 12:15 p.m.

Huckaby et al. (1995) give a general description of the ISS method and equipment. Pingel (1994) provides field sampling information for the tank TX-118 September 1994 ISS event, and Mahon (1995) provides revised sample volume measurements. In addition to the hydrogen cyanide results presented below, Thomas et al. (1995) and Rasmussen (1994) provide sample analysis results.

\subsection{December 1994 Vapor Sampling System Sampling Event}

Headspace gas and vapor samples were collected from tank TX-118 using the VSS on December 16, 1994 by WHC Sampling and Mobile Laboratories (WHC 1995b). Sample collection and analysis were performed as directed by Tank 241-TX-118 Tank Characterization Plan (the TCP), (Carpenter 1994). The tank headspace temperature was determined to be $21.5^{\circ} \mathrm{C}$. Air from the TX-118 headspace was withdrawn from a single elevation via a 7.9-m long heated sampling probe mounted in riser $9 \mathrm{~A}$, and transferred via heated tubing to the VSS sampling manifold. All heated zones of the VSS were maintained at approximately $50^{\circ} \mathrm{C}$. All tank air samples were collected between 10:30 a.m. and 2:15 p.m., with no anomalies noted.

Sampling media were prepared and analyzed by WHC, Oak Ridge National Laboratories (ORNL), and Pacific Northwest Laboratories (PNL). The 32 tank air samples and 2 ambient air control samples collected during the December sampling event are listed in Table 2-1 by analytical laboratory. Table 2-1 also lists the 13 trip blanks and 1 field blank provided by the laboratories.

A general description of vapor sampling and sample analysis methods is given by Huckaby et al. (1995). The sampling equipment, sample collection sequence, sorbent trap sample air fiow rates and flow times, chain of custody information, and a discussion of the sampling event itself are given in WHC (1995b). 
WHC-SD-WM-ER-449 REV. 1

\subsection{INORGANIC GASES AND VAPORS}

Analytical results of sorbent trap and SUMMA ${ }^{\mathrm{TM}, 1}$ canister tank air samples for selected inorganic gasés and vapors are given in Table 3-1 in parts per million by volume (ppmv) in dry air. The concentration of water vapor given in Table 3-1 has been adjusted to tank conditions as given in Section 3.3. Inorganic analyte sorbent traps and SUMMA ${ }^{\mathrm{TM}}$ were prepared and analyzed at PNL quality assurance impact level 2 (Lucke et al. 1995a). PNL analyses of SUMMA ${ }^{\text {TM }}$ canisters and sorbent traps for inorganic compounds were performed 64 and 30 days, respectively, after sample collection (Ligotke 1995). Sorbent trap analyses were within the the administratively chosen 60-day holding time requirement of the WHC quality assurance project plan (Keller 1994), but the SUMMA ${ }^{\text {TM }}$ canister analyses exceeded this. Though no holding time study has been performed to determine the stability of inorganic gases and vapors in SUMMA ${ }^{T M}$ canisters in the chemical matrix of the tank samples, these compounds would be expected to be quite stable, and exceeding the holding may not have affected the results.

Analyses of the hydrogen cyanide sorbent traps collected in September 1994 were performed within 9 days of sample collection. Sample preparation and analyses were conducted at PNL quality assurance impact level 3 (Thomas at al. 1995).

\subsection{Ammonia, Hydrogen, and Nitrous Oxide}

Ammonia concentration in the headspace of tank TX-118 was measured at 33 ppmv. Ammonia has been observed in virtually all of the waste tanks sampled to date, at concentrations ranging from about $3 \mathrm{ppmv}$ in tank C-108 (Lucke et al. 1995b), to 1040 ppmv in BY-108 (McVeety et al. 1995). Given the LFL of ammonia in air is about $15 \%$ by volume (vol\%), the measured 33 ppmv corresponds to about $0.02 \%$ of the LFL, and does not contribute appreciably to the flammability of the headspace.

The concentration of hydrogen in tank TX-118 was measured to be $<94$ ppmv by PNL. Hydrogen in the waste tanks is of concern as a fuel. Given that the for hydrogen in air is about $4 \mathrm{vol} \%$, the upper bound of 97 ppmv hydrogen concentration in tank TX-118 corresponds to about $0.24 \%$ of its LFL. At this level, hydrogen is not a flammability concern in tank TX-118.

The nitrous oxide concentration in tank TX-118 was measured to be 29 ppmv by PNL. Nitrous oxide has been detected in other passively ventilated waste tanks at concentrations as low as about 12 ppmv in tank TX-105 (Klinger et al. 1995), and as high as about 868 ppmv in tank U-103 (Ligotke et al. 1995). Under the proper conditions, nitrous oxide can serve as an oxidizer to support combustion. However, Cashdollar et al. (1992) found that nitrous oxide had no significant effect on the flammability of hydrogen and air mixtures for hydrogen concentrations less than $20 \mathrm{vol} \%$, and that "small amounts of nitrous oxide (relative to air) do not appear to have much effect on the flammability". Their results suggest the measured nitrous oxide concentration is much too low to have a significant effect on the flammability of the tank TX-118 headspace.

\subsection{Carbon Monoxide and Carbon Dioxide}

Carbon monoxide was determined to be $<12$ ppmv in each of the 3 SUMMA ${ }^{\mathrm{TM}}$ canister samples. Carbon monoxide in ambient air typically ranges from 0.05 to $0.15 \mathrm{ppmv}$. Elevated waste tank headspace carbon monoxide concentrations are common, and are thought to be due to the decomposition of organic waste in

1 SUMMA is a trademark of Molectrics, Inc., Cleveland, Ohio. 
WHC-SD-WM-ER-449 REV. 1

the tanks. Carbon monoxide have not been observed at very high levels in any of the waste tanks, the highest level measured to date was [26.7.ppmv] in tank C-103² (Huckaby and Story 1994).

The carbon dioxide concentration in the tank TX-118 headspace was measured to be 98 ppmv. Carbon dioxide is normally present in the ambient air at a concentration of 350 to $400 \mathrm{ppmv}$, and is typically lower than ambient in the waste tank headspaces. Carbon dioxide introduced by air exchange with the atmosphere is readily absorbed by caustic supernatant and interstitial liquids of the waste tanks, and converted to carbonate in solution. Carbon dioxide is neither toxicologically important nor flammable, but because it can be measured at the same time as other gases, and may help characterize the waste, it has been an inorganic target analyte.

\subsection{Nitric Oxide, Nitrogen Dioxide, Water and Tritium}

Nitric oxide and nitrogen dioxide concentrations in the tank TX-118 headspace were determined to be 0.42 ppmv and $\$ 0.03$ ppmv, respectively. These are both acid gases that would have very low equilibrium concentrations above the high pH sludge in tank TX-118. The measurable presence of nitric oxide may be due to its formation from oxygen and nitrogen in the radiation field of the headspace. These constituents could potentially serve as oxidizers to support combustion, but at the measured concentrations would have a negligible effect on the flammability of the tank TX-118 headspace.

The water vapor concentration of tank TX-118 was determined to be about $8.0 \mathrm{mg} / \mathrm{L}$, at the measured tank headspace temperature of $21.5^{\circ} \mathrm{C}$ and pressure of $989 \mathrm{mbar}$ (742.1 torr), (WHC 1995b). This corresponds to a water vapor partial pressure of $10.8 \mathrm{mbar}\left(8.1\right.$ torr), to a dew point of $8.1^{\circ} \mathrm{C}$, and to a relative humidity of $42 \%$.

Silica gel sorbent traps were used to test for tritium. It is assumed that tritium produced by the waste combines with hydroxide ions to form tritium-substituted water. Evaporation of the tritium-substituted water would then result in airborne radioactive contamination. Silica gel sorbent traps adsorb virtually all (normal and tritium-substituted) water vapor from the sampled tank air, and are analyzed at the WHC 222-S laboratory. Radiochemical analysis of the silica gel trap indicated the total activity of the headspace to be less than $50 \mathrm{pCi} / \mathrm{L}$ (WHC 1995b).

\subsection{Hydrogen Cyanide}

Analysis of the hydrogen cyanide specific sorbent traps indicated the concentration of this analyte to below $0.02 \mathrm{ppmv}$ in all 3 samples (Thomas et al. 1995). The absence of hydrogen cyanide at measurable concentrations is consistent with the expectation that an acid gas, such as hydrogen cyanide, would not exist at significant concentrations above the caustic waste in tank TX-118. No hydrogen cyanide has been detected in any of the 10 waste tank headspaces sampled for this analyte

\subsection{Discussion of Inorganic Gases and Vapors}

Aside from water and carbon dioxide, the most abundant waste constituents in the tank TX-118 headspace are ammonia and nitrous oxide. These have been detected in most tank headspaces sampled to date, and with hydrogen, are usually the dominate waste species.

\footnotetext{
${ }^{2}$ The carbon monoxide measurement in tank C-103 was made by Oregon Graduate Institute of Science
} and Technology, and placed in brackets to emphasize it should be considered secondary data. 


\section{WHC-SD-WM-ER-449 REV. 1}

The relative standard deviations of the inorganic gas and vapor results given in the last column in Table 3-1 are good, with the exception of the nitrous oxide measurement. Relative standard deviations range from about $1 \%$ for hydrogen to $84 \%$ for the PNL nitrous oxide measurement. The relatively poor precision of the PNL nitrous oxide measurements was apparently due to the fact that they are close to the PNL. detection limit. Because the precision reported depends both on sampling parameters (e.g., sample flow rate and flow time for sorbent traps) and analytical parameters (e.g., sample preparation, dilutions, etc.), the relative standard deviations suggest proper control was maintained both in the field and in the laboratories. 


\section{WHC-SD-WM-ER-449 REV. 1}

\subsection{ORGANIC VAPORS}

Organic vapors in the tank TX-118 headspace were sampled using SUMMATM canisters, which were analyzed by PNL, and triple sorbent traps (TSTs), which were analyzed by ORNL. Both PNL and ORNL used a gas chromatograph (GC) equipped with a mass spectrometer (MS) detector to separate, identify, and quantitate the analytes. OGIST analyzed 3 SUMMA ${ }^{\text {TM }}$ canister samples from the September 1994 sampling event for total nonmethane organic carbon (TNMOC) using the EPA task order 12 (TO-12) method (EPA 1988). Descriptions of sample device cleaning, sample preparations, and analyses are given by Jenkins et al. (1995a), Rasmussen (1994), and Lucke et al. (1995a).

SUMMA ${ }^{T M}$ sample results should be considered to be the primary organic vapor data for $\operatorname{tank} T X-118$. PNL results were produced at PNL quality assurance impact level 2 . All PNL analyses were completed 92 days after sample collection, and exceeded the WHC qualtiy assurance project plan 60-day holding time (Keller 1994). The 60-day holding time was administratively chosen, because no holding time study has been performed to determine the stability of analytes in SUMMA ${ }^{\mathrm{TM}}$ canisters in the chemical matrix of the tank samples.

ORNL analyses of TST samples from this and other waste tanks generally agree with, support, and augment the SUMMATM sample results. However, because certain WHC quality assurance reguirements were not satisfied by ORNL, the quality assurance assessment of ORNL by Hendrickson (1995) should be reviewed before results unique to the TST samples are used for decision making.

All TSTs prepared by ORNL had 3 surrogate compounds added to evaluate sample matrix effects, potential handling, storage, and shipment problems, and analytical instrumentation performance (Jenkins et al. 1995a). ORNL evaluated the surrogate recoveries using a statistical approach similar to that prescribed by SW 846 Method 8260 A Volatile Organic Compounds by Gas Chromatography/Mass Spectrometry (GC/MS) Capillary Column Technique (EPA 1992). Using this approach, ORNL reported that all surrogates had standard deviation values within the $95 \%$ confidence interval for variance, indicating that no bias was introduced in the measurement of analyte quantities (Jenkins 1995a).

\subsection{Positively Identified Organic Compounds}

Positive identification of organic analytes using the methods employed by PNL and ORNL involves matching the GC retention times and MS data from a sample with that obtained when known compounds were analyzed. The concentration of an analyte in the sample is said to be quantitatively measured if the response of the GCMS has been established at several known concentrations of that analyte (i.e., the GCMS has been calibrated for that analyte), and the MS response to the analyte in the sample is between the lowest and highest responses to the known concentrations (i.e., the analyte is within the calibration range).

ORNL and PNL were assigned different lists of organic compounds, or target analytes, to positively identify and measure quantitatively. The ORNL target analyte list was derived from a review of the tank C-103 headspace constituents by a panel of toxicology experts (Mahlum et al. 1994). The PNL target analyte list was 40 compounds in the Environmental Protection Agency (EPA) task order 14 (TO-14) method list, which consists primarily of halocarbons and common industrial solvents, plus 14 analytes selected from the toxicology panel's review of tank C-103.

Table 4-1 lists the organic compounds positively identified and quantitated in SUMMA ${ }^{\mathrm{TM}}$ samples. Analyses for methane were performed with the inorganic gas analyses, other SUMMA ${ }^{\mathrm{TM}}$ analyses were performed according to the Environmental Protection Agency (EPA) task order 14 (TO-14) methodology by PNL (EPA 1988 , Lucke et al. 1995a). The quantitation limit for all the target analytes was 0.005 ppmv. 


\section{WHC-SD-WM-ER-449 REV. 1}

Trichlorofluoromethane was the only analyte of the 40 TO-14 target analytes reported to be above the quantitation limit, and only 2 of the 14 additional target analytes were reported to be above the quantitation limit. Averages reported are from analyses of 3 SUMMA ${ }^{\mathrm{TM}}$ canister samples.

Jenkins et al. (1995a) report the positive identification of 25 of 27 target analytes in TST samples. Dibutyl butylphosphonate and tributyl phosphate were the only target analytes not detected in the TST samples. The sampling method is thought to affect these low volatility compounds, however, and their absence in the TST samples does not prove they are not in the tank headspace. 1,1-Dichloroethene was positively jidentified in 2 of the 3 TSTs analyzed, but its concentration was too low to be quantitatively measured. The average concentrations of 15 quantitated analytes, from the analysis of 3 TSTs, are given in Table 4-2. Table 4-3 lists 5 positively identified compounds that were not quantitated because their measurement in at least 1 TST sample was outside the instrument calibration range. Table 4-4 lists the 5 remaining compounds for which the analyte-specific ORNL practical holding time was exceeded. Data in Table 4-3 should not be considered quantitative, and data in Tables 4-3 and 4-4 may not be accurate to within $\pm 30 \%$ as specified by Burnum (1995).

The ORNL practical hoiding time is defined as the holding time for which there is a $15 \%$ risk that the concentration of an analyte in the sample will be below its initial concentration. As indicated in Table 4-4, propanone, butanal, 1-butanol, 2-pentanone, and n-pentanenitrile exceeded their practical holding times, and may have been affected by the 58 day period between sample collection and analysis (Jenkins 1995b). Jenkins et al (1995b) describe the ORNL practical holding time study, and report practical holding times for these compounds. It should be noted that the contractual holding time for the TST samples was 60 days.

Eleven target analytes were common to both TST and SUMMA'M analyses. Table 4-5 lists these, and their reported average concentrations in TST and SUMMA ${ }^{\mathrm{TM}}$ samples. The reported TST sample concentrations of chlorinated compounds (i.e., 1,1-dichloroethene and dichloromethane) and nonpolar compounds (i.e., benzene, toluene, $n$-hexane, $n$-heptane, and n-decane) in Table 4-5 are all $<0.009$ ppmv, and near or below the SUMMA ${ }^{T M}$ analysis method detection limit of 0.005 ppmv.

The propanone concentration in the SUMMA ${ }^{\mathrm{TM}}$ samples was reported to be 2.5 times as high as in TST samples. There is a similar disagreement regarding nitrile concentrations in SUMMA ${ }^{\mathrm{TM}}$ and TST samples from tank TX-118. As shown in Table 4-4, the average concentrations of ethanenitrile, propanenitrile, and n-butanenitrile in TST samples were well above the 0.005 ppmv SUMMA ${ }^{T M}$ method detection limit, yet these analytes were not found in the SUMMA ${ }^{T M}$ samples. In lieu of reasons to discount the TST results, they should be used as the best measurement of these nitriles.

\subsection{Tentatively Identified Organic Compounds}

In addition to the target analytes, the ORNL and PNL analytical procedures allow the tentative identification of other organic compounds. Tentative identification of analytes was performed by comparing the MS molecular fragmentation patterns with a library of known MS fragmentation patterns. This method allows an organic analyte to be identified (with reasonable certainty) as an alkane, a ketone, an aldehyde, etc., and may also determine its molecular weight. The method usually does not, however, allow the unambiguous identification of structural isomers, and this ambiguity increases with analyte molecular weight. Using this method, many analytes can be tentatively identified with reasonable confidence without having to inject each into the GCMS to determine their GC retention times or specific MS patterns.

By the nature of the sampling devices, virtually all organic vapors present in the tank headspace are collected by both TST and SUMMA ${ }^{\text {TM }}$ samples. Analyses of the samples are designed to recover, separate, and identify the organic vapors in the samples. TSTs are not good for collecting highly volatile compounds (i.e., molecules more volatile than propane), but are quite good for most others. In contrast, 


\section{WHC-SD-WM-ER-449 REV. 1}

the recovery of very low volatility compounds (i.e., molecules with more than about 15 carbon atoms) and some polar compounds with moderate volatility (i.e., butanal) from SUMMA'TM samples has been problematic.

The list of tentatively identified compounds recovered from SUMMA ${ }^{\text {TM' }}$ samples, with estimated concentrations, is given in Table 4-6. In Table 4-6, only non-zero results are included in the reported averages. The list of tentatively identified compounds detected in TST samples, and their estimated concentrations, is given in Table 4-7. The averages reported by ORNL in Table 4-7 are all 3-sample averages, and if an analyte was not detected in a sample, its concentration in that sample was considered to be zero for averaging purposes. Estimated concentrations are in $\mathrm{mg} / \mathrm{m}^{3}$, based on dry air at $0{ }^{\circ} \mathrm{C}$ and 1.01 bar.

Because the list of tentatively identified organic compounds in TST samples is long and locating any given compound may be difficult, the list has been sorted alphanumerically by compound name in Table 4-8, and also in order of decreasing estimated concentrations in Table 4-9. Numbers in the first columns of Tables 4-8 and 4-9 (Cmpd ) identify the location of the compound in Table 4-7

The ORNL and PNL methods used to tentatively identify and estimate concentrations are described by Jenkins et al. (1995) and Lucke et al. (1995a), respectively, and should be reviewed before this data is used for decision making. The proper quantitation of all observed analytes is outside the scope and budget of these analyses, and the estimation of concentrations involves several important assumptions. The validity of each assumption depends on the analyte, and such factors as the specific configuration of the analytical instrumentation.

Concentrations given in Tables 4-6 through 4-9 should be considered rough estimates. Results in Tables 4-6 through 4-9 are presented in terms of observed peaks, and are not adjusted for the occurrence of split chromatographic peaks (e.g., Cmpd \# 9 and 10 in Table 4-7) or the assignment of the same identity to different peaks (e.g., Cmpd \# 71, 78, and 85 in Table 4-7). In these instances, the estimated concentration of a compound appearing as a doublet or triplet is simply the sum of the individual peak estimates.

\subsection{Total Nonmethane Organic Carbon}

OGIST measured the TNMOC concentration in 3 SUMMATM canister samples from the September 1994 ISS event using the EPA TO-12 method (Rasmussen 1994). The sample mean was $\left[9.2 \mathrm{mg} / \mathrm{m}^{3}\right]$, with a standard deviation of $\left[0.4 \mathrm{mg} / \mathrm{m}^{3}\right]$. This value is about average for other passively ventilated tanks that have been sampled. Because OGIST did not have a WHC-approved quality assurance project plan in place at the time of analyses, OGIST data should be considered secondary data.

\subsection{Discussion of Organic Compounds}

A convenient way to consider the organic compounds listed in Tables 4-1 through 4-7 is to separate them into 2 categories: 1) Organic compounds added to tank TX-118 as waste that are still evaporating; and 2) organic compounds that have been generated by reactions of the original waste.

The first category encompasses all organic compounds that were placed into the tank as waste. It includes the semivolatile branched alkanes and NPHs, which were used as diluents of tributyl phosphate in several processes. It also includes volatile halogenated compounds, such as the trichlorofluoromethane, which may have been used as solvents in various cleaning operations, and which may have been sent to the waste tanks when contaminated. The tentatively identified hexamethylcyclosiloxane (i.e., Cmpd \# 45 in Table 4-7) is also in this category. Small quantities of siloxanes may have been introduced to the waste 


\section{WHC-SD-WM-ER-449 REV. 1}

tank through their use as process surfactants, but they may also be present in the headspace due to their use in liquid traps at the tank's breather riser.

Two polychlorinated biphenyls (PCBs) were tentatively identified in TST samples from tank TX-118. 3Chloro-1,1'-biphenyl and 3,3'-dichloro-1,1'-biphenyl (Cmpd \# 102 and 104 in Table 4-7) were each estimated to be at about $0.005 \mathrm{mg} / \mathrm{m}^{3}$ in the samples. These compounds were used in industry, and presumably at Hanford, in a wide variety of applications as cutting oils, in electrical transformers, lubricants, etc., and their detection in tank TX-118, if valid, could be due to the disposal of small quantities of radiolytically contaminated fluids.

The second category includes all organic compounds that have been generated via radiolytic and chemical reactions of the waste. The majority of compounds listed in Tables 4-1 through 4-7 fall into this category, including the alcohols, aldehydes, ketones, nitriles, alkenes, alkyl nitrates, and volatile alkanes, all of which have been associated with the degradation of the NPHs. The hydrolysis of tributyl phosphate, for example, is thought to be the principal source of 1-butanol. By far the most abundant of these in the headspace are the short-chain volatile compounds, however, Table 4-7 lists several long-chain low volatility compounds that are also probably waste reaction products.

A large number of nitriles were found in TST samples from tank TX-118. In addition to the homologous series of straight-chain nitriles from ethanenitrile through decanenitrile, there are also several short unsaturated nitriles and benzonitrile.

Samples from tank TX-118 were found to have a strong signature of organic nitrogen oxides, including alkyl nitrates (i.e., nitric acid esters), alkyl nitrites (i.e., nitrous acid esters), and nitroalkanes. Considering both Tables 4-1 and 4*6, 5 of the 27 most abundant organic compounds detected in SUMMA ${ }^{\mathrm{TM}}$ samples from tank $T X-118$ are nitrates, and methyl nitrite and nitrosomethane are also amongst the top 27 . Such compounds were also detected in TST samples, and they are similarly well represented in Table 4-9.

Though it is reasonable to expect alkyl nitrates and nitrites to be produced via chemical and radiolytic processes of the NPHs with other waste, their solubility in the aqueous waste supernate would also be expected to significantly reduce their vapor-phase concentrations. That these constituents are at detectible levels in tank TX-118 may indicate dry conditions where they are formed.

In summary, the organic vapor concentrations in tank TX- 118 are relatively low. While not completely typical of NPH-rich tanks, the organic vapors in tank TX-118 clearly indicate the presence of trace amounts of the semivolatile NPHs and their degradation products. At the reported concentrations, the organic vapors identified in TX-118 do not individually or collectively represent a flammability hazard. 


\subsection{SUMMARY}

The tank TX-118 headspace was sampled in September 1994 and again in December 1994 for gases and vapors to address flammability and industrial hygiene concerns. Collection and analysis of samples has been reported. It was determined that no headspace constituents exceeded the flammability or indrustrial hygiene notification limits specified in the current Vapor Sampling and Analysis Plan (Homi 1995b). 


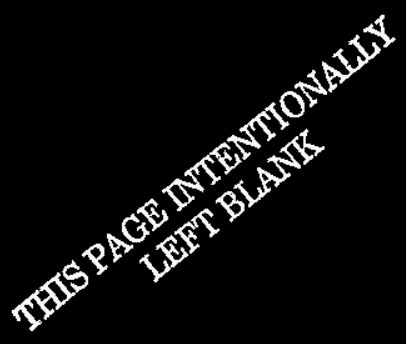




\subsection{REFEPRENCES}

29 CFR 1910.120, 1993, "Hazardous Waste Operations and Emergency Response", Code of Federal - Regulations.

Burnum, S. T., 1995, Qualification of Reported WHC Vapor Program Data, (letter 95-CHD-065 to president, Westinghouse Hanford Company, August 18), Department of Energy, Richland Operations Office, Richland, Washington.

Carpenter, B. C., 1994, Tank 241-TX-118 Tank Characterization Plan, WHC-SD-WM-TP-241 Rev. 0, Westinghouse Hanford Company, Richland, Washington.

Cashdollar, K. L., M. Hertzberg, I. A. Zlochower, C. E. Lucci, G. M. Green, and R. A. Thomas, 1992, Laboratory Flammability Studies of Mixtures of Hydrogen, Nitrous Oxide, and Air, WHC-SD-WMES-219 Rev. 0, Westinghouse Hanford Company, Richland, Washington.

Dougherty, L. F., 1995, Single Shell Tank Interim Operational Safety Requirements, WHC-SD-WM-OSR005 Rev. 0, Westinghouse Hanford Company, Richland, Washing

EPA 1988, Compendium of Methods for the Determination of Toxic Organic Compounds in Ambient Air, PB90-127374, U.S. Environmental Protection Agency, Washington, D.C.

EPA 1992, Test Methods for Evaluating Solid Waste, SW-846 Rev. 1, U.S. Environmental Protection Agency, Washington, D.C.

Farley, W. G., 1991, Safety Assessment for Gas Sampling All Ferrocyanide Tanks, WHC-SD-WM-SAD-009 Rev. 2, Westinghouse Hanford Company, Richland, Washington.

Hendrickson, R. W., 1995, Tank Vapor Characterization Oak Ridge National Laboratories Quality Assurance Assessment, TWRSQA-95-0012, Westinghouse Hanford Company, Richland, Washington.

Homi, C. S., 1995, Vapor Sampling and Analysis Plan, WHC-SD-WM-TP-335 Rev. 0G, Westinghouse Hanford Company, Richland, Washington.

Huckaby, J. L., 1994a, Vapor Sampling System (VSS) and In Situ Sampling (ISS) Method Comparison, WHC-SD-WM-RPT-101 Rev. 0, Westinghouse Hanford Company, Richland, Washington.

Huckaby, J. L., 1994b, Tank 241-C-103 Headspace Flammability, WHC-EP-0734 Rev. 1, Westinghouse Hanford Company, Richland, Washington.

Huckaby, J. L., H. Babad, and D. R. Bratzel, 1995, Headspace Gas and Vapor Characterization Summary for the 43 Vapor Program Suspect Tanks, WHC-SD-WM-ER-514, Rev. 0, Westinghouse Hanford Company, Richland, Washington.

Huckaby, J. L., and M. S. Story, 1994, Vapor Characterization of Tank 241-C-103, WHC-EP-0780 Rev. 0, Westinghouse Hanford Company, Richland, Washington.

Jenkins, R. A., 1995a, Untitled, (Letter 090195A to D. Bratzel, September 1), Oak Ridge National Laboratory, Oak Ridge, Tennessee. 
Jenkins, R. A., 1995b, Untitled, (Letter 091495A to D. Bratzel, September 14), Oak Ridge National Laboratory, Oak Ridge, Tennessee.

Jenkins, R. A, A. B. Dindal, C. Y. Ma, M. A. Palausky, J. T. Skeen, and C. K. Bayne, 1995a, Analysis of Tank 241-TX-118 Headspace Components, ORNL-CASD-FR-241TX118.95 Rev. 0, Oak Ridge National Laboratory, Oak Ridge, Tennessee.

Jenkins, R. A, A. B. Dindal, C. Y. Ma, M. A. Palausky, J. T. Skeen, and C. K. Bayne, 1995b, Analysis of Tank 241-TY-104 Headspace Components, ORNL-CASD-FR-241TY104.95 Rev. 1, Oak Ridge National Laboratory, Oak Ridge, Tennessee.

Keller, K. K., 1994, Quality Assurance Project Plan for Tank Vapor Characterization, WHC-SD-WM-QAPP013 Rev. 2, Westinghouse Hanford Company, Richland, Washington.

Klinger, G. S., T. W. Clauss, M. W. Ligotke, K. H. Pool, R. B. Lucke, B. D. McVeety, O. P. Bredt, J. S. Young, M. McCulloch, J. S. Fruchter, and S. C. Goheen, 1995, Vapor Space Characterization of Waste Tank 241-TX-105: Results from Samples Collected Through the Vapor Sampling System on 12/20/94, PNL-10594 UC-606, Pacific Northwest Laboratory, Richland, Washington.

Ligotke, M. W., 1995, PNL Vapor Project Analytical Holding Times, (Letter to D. R. Bratzel, September 23 , 1995) Pacific Northwest Laboratory, Richland, Washington.

Ligotke, M. W., K. H. Pool, T. W. Clauss, B. D. McVeety, G. S. Klinger, K. B. Olsen, O. P. Bredt, J. S. Fruchter, and S. C. Goheen, 1995, Vapor Space Characterization of Waste Tank 241-U-103: Results from Samples Collected on 2/15/95, PNL-10813 UC-606, Pacific Northwest Laboratory, Richland, Washington.

Lucke, R. B., T. W. Clauss, M. W. Ligotke, K. H. Pool, B. D. MoVeety, G. S. Klinger, K. B. Olsen, M. McCulloch, J. S. Fruchter, and S. C. Goheen, 1995a, Vapor Space Characterization of Waste Tank 241-TX-118: Results from Samples Collected Through the Vapor Sampling System on 12/16/94, PNL-10625 UC-606, Pacific Northwest Laboratory, Richland, Washington.

Lucke, R. B., M. W. Ligotke, K. H. Pool, T. W. Clauss, A. K. Sharma, B. D. McVeety, M. McCulloch, J. S. Fruchter, and S. C. Goheen, 1995b, Vapor Space Characterization of Waste Tank 241-C-108: Results from Samples Collected Through the Vapor Sampling System on 8/5/94, PNL-10351 UC606, Pacific Northwest Laboratory, Richland, Washington.

Mahon, R., 1995, FY 1994 In-Situ Sampling System Summary Report, (Letter OM624-95-055 to D.Bratzel), Westinghouse Hanford Company, Richland, Washington

Mahlum, D. D., J. Y. Young, and R. E. Weller, 1994, Toxicologic Evaluation of Analytes from Tank 231-C. 103, PNL-10189, Pacific Northwest Laboratory, Richland, Washington.

McVeety, B. D., T. W. Clauss, M. W. Ligotke, K. H. Pool, R. B. Lucke, G. S. Klinger, J. S. Young, M. McCulloch, J. S. Fruchter, and S. C. Goheen, 1995, Vapor Space Characterization of Waste Tank 241-BY-108: Results from Samples Collected on 10/27/94, PNL-10495 UC-606, Pacific Northwest Laboratory, Richland, Washington. 
Meacham, J. E., H. Babad, R. J. Cash, G. T. Dukelow, S. J. Eberlein, D. W. Hamilton, G. D. Johnson, J. W. Osborne, M. A. Payne, D. J. Sherwood, D. A. Turner, and J. L. Huckaby, 1995, Approach for Tank Safety Characterization of Hanford Site Waste, WHC-EP-0843 Rev. 0, UC-2070, Westinghouse Hanford Company, Richland, Washington.

NFPA 1992, Standard on Explosion Prevention Systems, NFPA 69, National Fire Protection Association, Quincy, Massachusetts.

Osborne, J. W., and J. L. Huckaby, 1994, Program Plan for the Resolution of Tank Vapor /ssues, WHC-EP0562 Rev. 1, Westinghouse Hanford Company, Richland, Washington.

Osborne, J. W., J. L. Huckaby, T. P. Rudolph, E. R. Hewitt, D. D. Mahlum, J. Y. Young, and C. M. Anderson, 1994, Data Quality Objectives for Generic In-Tank Health and Safety Issue Resolution, WHC-SD-WM-DQO-002, Westinghouse Hanford Company, Richland, Washington.

Pingel, L. A., 1994, Draft Report for the In-Situ Vapor Sampling of Waste Tank TX-118, (Internal memorandum 8E130-SAS94-113 to J. L. Huckaby, September 21), Westinghouse Hanford Company, Richland, Washington.

Rasmussen, R. A., 1994, Air Samples Collected at Waste Tank 241-TX-118 on September 7, 1994 by Westinghouse Hanford in 6-L SS SUMMA@ Canisters, Oregon Graduate institute of Science and Technology, Beaverton, Oregon

Thomas, B.L., T.W. Clauss, M.W. Ligotke, K.H. Pool, B.D. MoVeety, K.B. Olsen, J.S. Fruchter, S.C. Goheen, 1995, Vapor Space Characterization of Waste Tank 241-TX-118 (In-Situ): Results from Samples Collected on 9/7/94, PNL-10732 UC-606, Pacific Northwest Laboratory, Richland, Washington.

WHC 1995a, Operating Specifications for Watchlist Tanks, OSD-T-151-00030, Rev. B-9, Westinghouse Hanford Company, Richland, Washington.

WHC 1995b, Vapor and Gas Sampling of Single-Shell Tank 241-TX-118 Using the Vapor Sampling System, WHC-SD-WM-RPT-115, Westinghouse Hanford Company, Richland, Washington. 



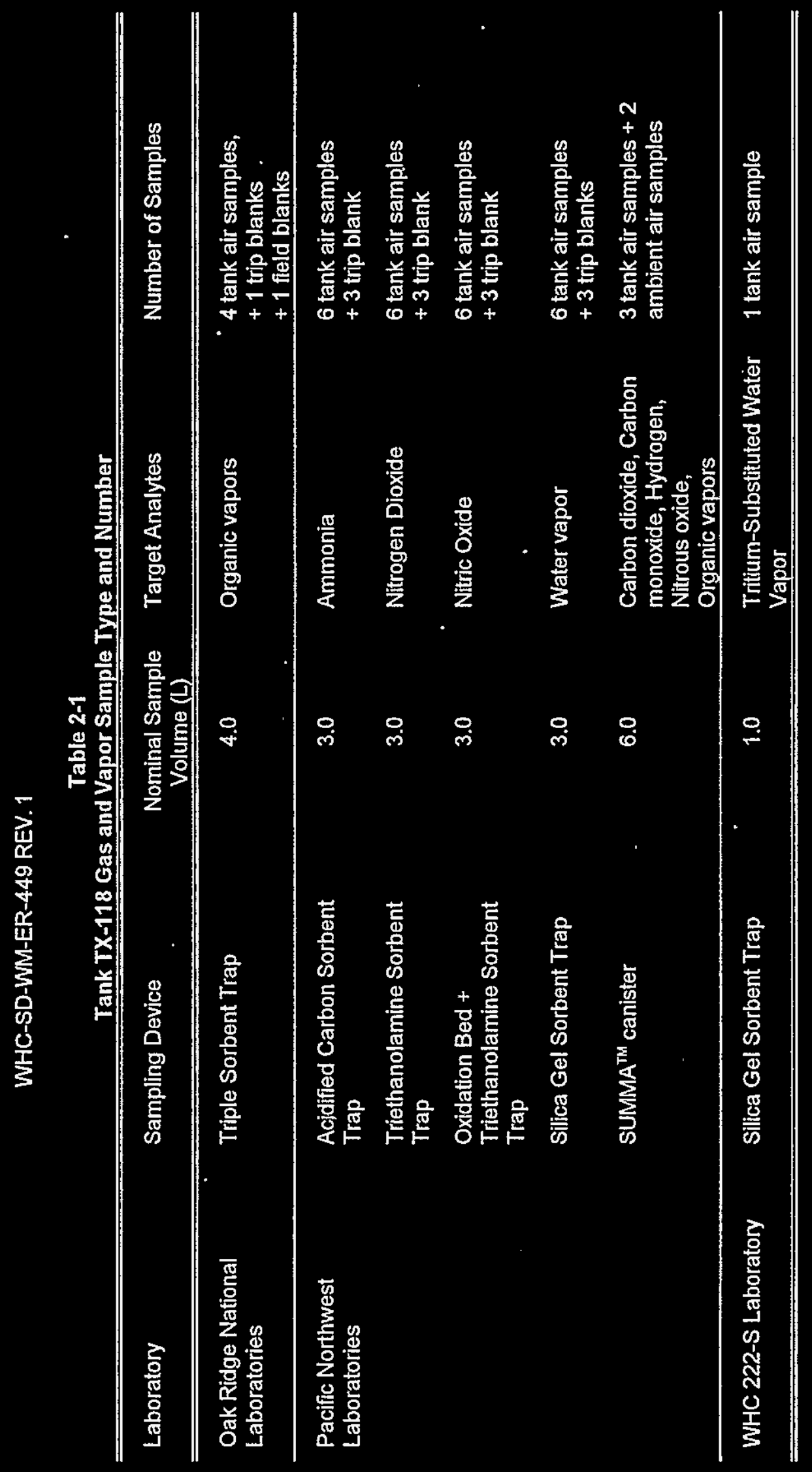




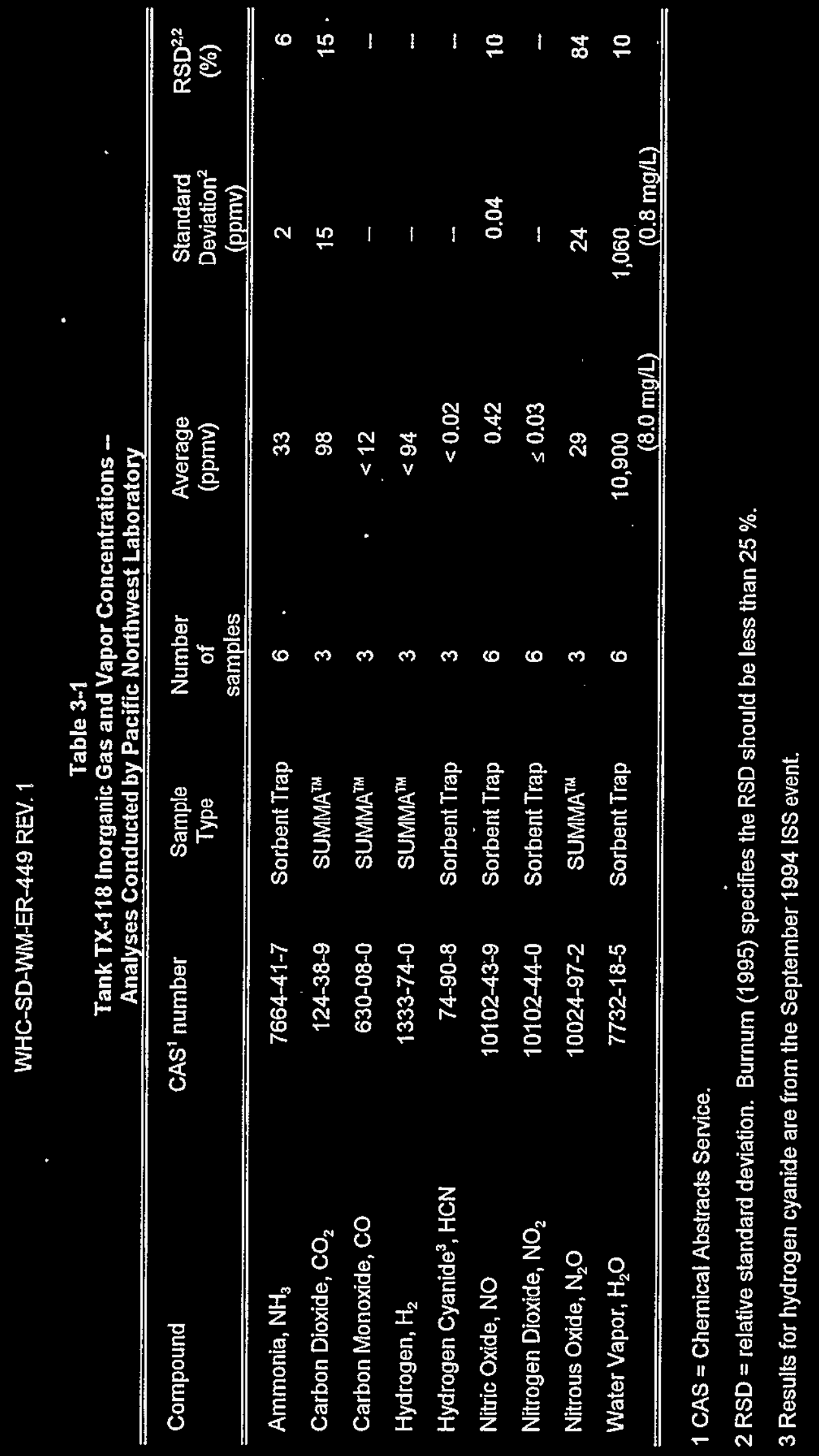


WHC்-SD-WM-ER-449 REV. 1

Table 4-1

Tank TX-118 Quantitatively Measured Organic Compounds in SUMMA ${ }^{\text {TM }}$ Samples Analyses by Pacific Northwest Laboratory

\begin{tabular}{clcccc}
\hline \hline $\begin{array}{c}\text { Cmpd } \\
\#\end{array}$ & Compound & $\begin{array}{c}\text { CAS }^{1} \\
\text { Number }\end{array}$ & $\begin{array}{c}\text { Average } \\
(\text { ppmv) }\end{array}$ & $\begin{array}{c}\text { Standard } \\
\text { Deviation } \\
(\mathrm{ppmv})\end{array}$ & $\begin{array}{c}\mathrm{RSD}^{3} \\
(\%)\end{array}$ \\
\hline \hline 1 & Methane $^{4}$ & $74-82-8$ & $<\mathrm{xxx}$ & - & - \\
2 & Trichlorofluoromethane & $75-69-4$ & 0.20 & 0.01 & 7 \\
3 & 2-Butanone & $78-93-3$ & 0.027 & 0.003 & 10 \\
4 & Propanone (acetone) & $67-64-1$ & 1.5 & 0.1 & 8 \\
\hline \hline
\end{tabular}

$1 \mathrm{CAS}=$ Chemical Abstract Service.

2 Average of 3 samples.

3 RSD = relative standard deviation. Burnum (1995) specifies the RSD should be less than $25 \%$.

4 Methane analyses were performed with analyses of the inorganic gases by PNL. 
Table 4-2

Tank TX-118 Quantitatively Measured Organic Compounds in TST Samples Analyses by Oak Ridge National Laboratory ${ }^{\prime}$

\begin{tabular}{|c|c|c|c|c|c|}
\hline Cmpd & Compound & $\begin{array}{c}\text { CAS }^{2} \\
\text { Number }\end{array}$ & $\begin{array}{c}\text { Average }^{3} \\
\text { (ppmv) }\end{array}$ & $\begin{array}{l}\text { Standard } \\
\text { Deviation } \\
\text { (ppmv) }\end{array}$ & $\begin{array}{c}\mathrm{RSD}^{4} \\
(\%)\end{array}$ \\
\hline 1 & Propanenitrile & $107-12-0$ & 0.018 & 0.001 & 6 \\
\hline 2 & n-Hexane & $110-54-3$ & 0.0074 & 0.0023 & 31 \\
\hline 3 & Benzene & $71-43-2$ & 0.0029 & 0.0008 & 29 \\
\hline 4 & n-Butanenitrile & $109-74-0$ & 0.019 & 0.005 & 27 \\
\hline 5 & n-Heptane & $142-82-5$ & 0.0088 & 0.0004 & 5 \\
\hline 6 & Toluene & $108-88-3$ & 0.0049 & 0.0005 & 9 \\
\hline 7 & 2-Hexanone & $591-78-6$ & 0.0062 & 0.0023 & 37 \\
\hline 8 & n-Octane & $111-65-9$ & 0.0065 & 0.0022 & 34 \\
\hline 9 & n-Hexanenitrile & $628-73-9$ & 0.0026 & 0.0003 & 13 \\
\hline 10 & 2-Heptanone & $110-43-0$ & 0.0045 & 0.0017 & 37 \\
\hline$\uparrow 1$ & n-Nonane & $111-84-2$ & 0.0043 & 0.0013 & 31 \\
\hline 12 & n-Heptanenitrile & $629-08-3$ & 0.0026 & 0.0005 & 20 \\
\hline 13 & n-Decane & $124-18-5$ & 0.0041 & 0.0016 & 38 \\
\hline 14 & n-Undecane & $1120-21-4$ & 0.0027 & 0.0003 & 11 \\
\hline 15 & n-Dodecane & $112-40-3$ & 0.0069 & 0.0022 & 32 \\
\hline
\end{tabular}

1 Results in this table are quantitative (as defined in Section 4.1).

$2 \mathrm{CAS}=$ Chemical Abstract Service.

3 Average of 3, 4-L. TST samples.

4.RSD $=$ relative standard deviation. Burnum (1995) specifies the RSD should be less than $25 \%$. 
WHC-SD-WM-ER-449 REV. 1

Table 4-3

Tank TX-118 Positively Identified Organic Compounds in TST Samples Analyses by Oak Ridge National Laboratory ${ }^{1}$

\begin{tabular}{|c|c|c|c|c|c|}
\hline$\underset{\#}{\text { Cmpd }}$ & Compound & $\begin{array}{c}\mathrm{CAS}^{2} \\
\text { Number }\end{array}$ & $\begin{array}{c}\text { Average }^{3} \\
\text { (ppmv) }\end{array}$ & $\begin{array}{l}\text { Standard } \\
\text { Deviation } \\
\text { (ppmy) }\end{array}$ & $\begin{array}{l}\mathrm{RSD}^{4} \\
(\%)\end{array}$ \\
\hline 1 & Ethanenitrile (acetonitrile) & 75-05-8 & 0.046 & 0.064 & 139 \\
\hline 2 & 1,1-Dichloroethene (vinylidene chloride) & $75-35-4$ & $<0.00058$ & - & - \\
\hline 3 & $\begin{array}{l}\text { Dichloromethane } \\
\text { (methylene chloride) }\end{array}$ & $75-09-2$ & 0.0066 & 0.0079 & 119 \\
\hline 4 & 2-Octanone & $111-13-7$ & 0.0011 & 0.0005 & 46 \\
\hline 5 & $\mathrm{n}$-Tridecane & $629-50-5$ & 0.021 & 0.0065 & 31 \\
\hline
\end{tabular}

1 Results in this table are not quantitative (as defined in Section 4.1) because measured values in at least 1 of the samples are outside instrument calibration limits.

$2 \mathrm{CAS}=$ Chemical Abstract Service.

3 Average of 3, 4-L TST samples.

4 RSD = relative standard deviation. Burnum (1995) specifies the RSD should be less than $25 \%$. 
WHC-SD-WM-ER-449 REV. 1

Table $4-4$

Tank TX-118 Positively Identified Compounds in TST Samples for which Practical Holding Times were Exceeded Analyses by Oak Ridge National Laboratory ${ }^{1}$

\begin{tabular}{clcccc}
\hline \hline $\begin{array}{c}\text { Cmpd } \\
\#\end{array}$ & Compound & $\begin{array}{c}\text { CAS }^{2} \\
\text { Number }\end{array}$ & $\begin{array}{c}\text { Average }^{3} \\
\text { (ppmv) }\end{array}$ & $\begin{array}{c}\text { Standard } \\
\text { Deviation } \\
\text { (ppmv) }\end{array}$ & $\begin{array}{c}\text { RSD }^{4} \\
(\%)\end{array}$ \\
\hline 1 & Propanone $^{6}$ (acetone) & $67-64-1$ & 0.60 & 0.06 & 10 \\
2 & Butanal $^{6}$ & $123-72-8$ & 0.062 & 0.034 & 54 \\
3 & 1-Butanol & $71-36-3$ & 0.27 & 0.04 & 15 \\
4 & 2-Pentanone & $107-87-9$ & 0.013 & 0.0001 & 5 \\
5 & n-Pentanenitrile & $110-59-8$ & 0.0056 & 0.0012 & 22 \\
\hline \hline
\end{tabular}

1 Practical holding times are defined and discussed in Section 4.1.

$2 \mathrm{CAS}=$ Chemical Abstract Service.

3 Average of 3, 4-L TST samples.

4 RSD = relative standard deviation. Burnum (1995) specifies the RSD should be less than $25 \%$.

5 The concentration of this analyte was not quantitatively measured (as defined in Section 4.1), because the measured concentration was outside of the instrumental calibration limits.

6 The concentration of this analyte is quantitatively measured (as defined in Section 4.1). 
Table 4-5

Tank TX-118 Comparison of Organic Compounds in TST and SUMMA ${ }^{\mathrm{TM}}$ Samples -Analyses by Pacific Northwest Laboratory and Oak Ridge National Laboratory

\begin{tabular}{lcccc}
\hline Compound & $\begin{array}{c}\text { CAS }^{1} \\
\text { Number }\end{array}$ & $\begin{array}{c}\text { TST } \\
\text { Average }^{2} \\
\text { (ppmv) }\end{array}$ & $\begin{array}{c}\text { SUMMA }^{\text {Average }} \\
\text { (ppmv) }^{3}\end{array}$ & $\begin{array}{c}\text { PRD }^{4} \\
(\%)\end{array}$ \\
\hline \hline $\begin{array}{l}\text { 1,1-Dichloroethene (vinylidene chloride) } \\
\text { Dichloromethane } \\
\text { (methylene chloride) }\end{array}$ & $75-35-4$ & $<0.00058$ & $<0.005$ & - \\
Propanone (acetone) & $75-09-2$ & 0.0066 & $<0.005$ & $>28$ \\
Ethanenitrile (acetonitrile) & $67-64-1$ & 0.60 & 1.5 & 86 \\
Propanenitrile & $75-05-8$ & 0.046 & $<0.005$ & $>161$ \\
n-Butanenitrile & $107-12-0$ & 0.018 & $<0.005$ & $>113$ \\
Benzene & $109-74-0$ & 0.019 & $<0.005$ & $>117$ \\
Toluene & $71-43-2$ & 0.0029 & $<0.005$ & - \\
n-Hexane & $108-88-3$ & 0.0049 & $<0.005$ & - \\
n-Heptane & $110-54-3$ & 0.0074 & $<0.005$ & $>39$ \\
n-Decane & $142-82-5$ & 0.0088 & $<0.005$ & $>55$ \\
\hline \hline
\end{tabular}

$1 \mathrm{CAS}=$ Chemical Abstract Service.

2 Average of 3, 4-L.TST samples by ORNL.

3 Average of 3 sample analyses by PNL.

$4 \mathrm{PRD}=$ percent relative difference. Keller $(1994)$ requires the PRD to be less than $20 \%$. 
Table 4-6

Tank TX-118 Tentatively Identified Organic Compounds in SUMMA ${ }^{\text {TM }}$ Samples -Analyses Conducted by Pacific Northwest Laboratory

\begin{tabular}{|c|c|c|c|c|}
\hline$\underset{\#}{\text { Cmpd }}$ & Compound & $\begin{array}{r}\text { CAS }^{1} \\
\text { Number }\end{array}$ & $\begin{array}{r}\text { Average } 2 \\
\left(\mathrm{mg} / \mathrm{m}^{3}\right)\end{array}$ & $\begin{array}{c}\text { Standard } \\
\text { Deviation } \\
\left(\mathrm{mg} / \mathrm{m}^{3}\right)\end{array}$ \\
\hline 1 & Propene & $115-07-1$ & 0.16 & 0.07 \\
\hline 2 & Propane & $74-98-6$ & 0.58 & 0.25 \\
\hline 3 & Methyl nitrite & $624-91-9$ & 0.60 & 0.05 \\
\hline 4 & Cyclopropane & $75-19-4$ & 0.076 & 0.008 \\
\hline 5 & Acetaldehyde ${ }^{4}$ & $75-07-0$ & 0.090 & 0.02 \\
\hline 6 & Methyl Alcohol & $67-56-1$ & 1.6 & 0.1 \\
\hline 7 & 1-Butene ${ }^{5}$ & $106-98-9$ & 0.057 & - \\
\hline 8 & Butane & $106-97-8$ & 0.13 & 0.01 \\
\hline 9 & Nitroso-Methane & $865-40-7$ & 0.19 & 0.02 \\
\hline 10 & Unknown & & 0.19 & 0.06 \\
\hline 11 & Ethanol & $64-17-5$ & 0.18 & 0.02 \\
\hline 12 & Isopropyl Alcohol & $67-63-0$ & -0.29 & 0.01 \\
\hline 13 & Unknown Alkylnitrate & & 0.18 & 0.11 \\
\hline 14 & 1-Propanol & $71-23-8$ & 0.22 & 0.02 \\
\hline 15 & 3-Methyl-2-Butanone & $563-80-4$ & $<0.01$ & - \\
\hline 16 & Butanal & $123-72-8$ & 0.23 & 0.01 \\
\hline 17 & Ethyl nitrate & $625-58-1$ & 0.13 & 0.01 \\
\hline 18 & Unknown ${ }^{5}$ & & 0.12 & - \\
\hline 19 & 1-Butanol & $71-36-3$ & 0.91 & 0.02 \\
\hline 20 & Propyl Nitrate & $627-13-4$ & 0.14 & $<0.005$ \\
\hline 21 & Butyl nitrate & $928-45-0$ & 0.10 & 0.01 \\
\hline 22 & 3-Heptanone & $106-35-4$ & 0.32 & 0.01 \\
\hline 23 & Unknown Alkylnitrate & & 0.091 & 0.002 \\
\hline \multicolumn{3}{|c|}{ Sum of tentatively identified compounds: } & 6.5 & \\
\hline
\end{tabular}

$1 \mathrm{CAS}=$ Chemical Abstract Service.

2 Average of 3 samples, values listed are estimates. 
WHC-SD-WM-ER-449 REV. 1 3 When the analyte was detected in only 2 samples, the entry is the relative difference (i.e., their difference
divided by 2).

4 Detected in only 2 samples.

5 Detected in only 1 sample. 
Table 4-7

Tank TX-118 Tentatively Identified Organic Compounds in TST Samples in Order of Chromatographic Elution Analyses Conducted by Oak Ridge National Laboratory

\begin{tabular}{|c|c|c|c|c|}
\hline$\underset{\#}{C \text { Cmpd }}$ & Compound & $\begin{array}{c}\text { CAS }^{1} \\
\text { Number }\end{array}$ & $\begin{array}{c}\text { Average }^{2} \\
\left(\mathrm{mg} / \mathrm{m}^{3}\right)\end{array}$ & $\begin{array}{l}\text { Standard } \\
\text { Deviation } \\
\left(\mathrm{mg} / \mathrm{m}^{3}\right)\end{array}$ \\
\hline 1 & Methyl nitrite & $624-91-9$ & 0.034 & 0.048 \\
\hline 2 & 1-Propene, 2-methyl- & $115-11-7$ & 0.043 & 0.007 \\
\hline 3 & Butane & $106-97-8$ & 0.034 & 0.016 \\
\hline 4 & Methyl Alcohol & $67-56-1$ & 0.39 & 0.10 \\
\hline 5 & 1-Propene, 2-methyl- & $115-11-7$ & 0.027 & 0.023 \\
\hline 6 & Nitrous acid, butyl ester & $544-16-1$ & 0.024 & 0.0003 \\
\hline 7 & Methane, dichlorofluoro- & $75-43-4$ & 0.0020 & 0.0030 \\
\hline 8 & Ethanol & $64-17-5$ & 0.18 & 0.05 \\
\hline 9 & Trichloromonofluoromethane & $75-69-4$ & 0.17 & 0.02 \\
\hline 10 & Trichloromonofluoromethane & $75-69-4$ & 0.013 & 0.023 \\
\hline 11 & Isopropyl Alcohol & $67-63-0$ & 0.16 & 0.02 \\
\hline 12 & Nitrous acid, butyl ester & $544-16-1$ & 0.012 & 0.001 \\
\hline 13 & 2-Propenenitrile & $107-13-1$ & 0.0020 & 0.0040 \\
\hline 14 & 2-Propanol, 2-methyl- & $75-65-0$ & 0.0054 & 0.0094 \\
\hline 15 & Nitric acid, ethyl ester & $625-58-1$ & 0.037 & 0.004 \\
\hline 16 & 1-Propañol & $71-23-8$ & 0.19 & 0.04 \\
\hline 17 & 3-Buten-2-one & $78-94-4$ & 0.013 & 0.002 \\
\hline 18 & 2-Butanone & $78-93-3$ & 0.087 & 0.035 \\
\hline 19 & Nitrous acid, butyl ester & $544-16-1$ & 0.028 & 0.005 \\
\hline 20 & Nitric acid, propyl ester & $627-13-4$ & 0.025 & 0.005 \\
\hline 21 & Furan, tetrahydro- & $109-99-9$ & 0.024 & 0.003 \\
\hline 22 & Butane, 1-chioro- & $109-69-3$ & 0.0021 & 0.0037 \\
\hline 23 & 3-Butenenitrile & $109-75-1$ & 0.0046 & 0.0040 \\
\hline 24 & 2-Butenal, (E)- & $123-73-9$ & 0.0064 & 0.0057 \\
\hline 25 & 2-Butanone, 3-methyl- & $563-80-4$ & 0.0024 & 0.0042 \\
\hline 26 & 2-Butenenitrile & $4786-20-3$ & -0.0071 & 0.0004 \\
\hline 27 & 3-Pentanone & $96-22-0$ & 0.011 & 0.010 \\
\hline
\end{tabular}


WHC-SD-WM-ER-449 REV. 1

\begin{tabular}{|c|c|c|c|c|}
\hline Cmpd & Compound & $\begin{array}{l}\text { CAS' } \\
\text { Number }\end{array}$ & $\begin{array}{l}\text { Average } \\
\left(\mathrm{mg} / \mathrm{m}^{3}\right)\end{array}$ & $\begin{array}{l}\text { Standard } \\
\text { Deviation } \\
\left(\mathrm{mg} / \mathrm{m}^{3}\right)\end{array}$ \\
\hline 28 & 2-Heptene, (E)- & $14686-13-6$ & 0.0047 & 0.0041 \\
\hline 29 & 1H-Pyrazole, 1-methyl- & $930-36-9$ & 0.0022 & 0.0038 \\
\hline 30 & 2-Butanone, 3,3-dimethyl- & $75-97-8$ & 0.015 & 0.002 \\
\hline 31 & 2-Heptene, (E)- & $14686-13-6$ & 0.0025 & 0.0043 \\
\hline 32 & Nitric acid, ethyl ester & $625-58-1$ & 0.028 & 0.006 \\
\hline 33 & Methyl Isobutyl Ketone & $108-10-1$ & 0.0059 & 0.0053 \\
\hline 34 & Propanoic acid & $79-09-4$ & 0.0046 & 0.0080 \\
\hline 35 & Pyrazine & $290-37-9$ & 0.0022 & 0.0038 \\
\hline 36 & Propane, 2-methyl-2-nitro- & $594-70-7$ & 0.018 & 0.004 \\
\hline 37 & 3-Pentanone, 2-methyl- & $565-69-5$ & 0.0024 & 0.0041 \\
\hline 38 & 1-Pentanol & $71-41-0$ & 0.022 & 0.005 \\
\hline 39 & Octane, 2-chloro- & $628-61-5$ & 0.0016 & 0.0027 \\
\hline 40 & 2-Pentanone, 4,4-dimethyl- & $590-50-1$ & 0.020 & 0.002 \\
\hline 41 & 3-Hexanone & $589-38-8$ & 0.0051 & 0.0013 \\
\hline 42 & 1-Hexanol & $111-27-3$ & 0.0049 & 0.0084 \\
\hline 43 & $\begin{array}{l}\text { 2-Furanmethanol, tetrahydro-5-methyl-, } \\
\text { trans- }\end{array}$ & $54774-28-6$ & 0.0011 & 0.0019 \\
\hline 44 & Tetrachloroethylene & $127-18-4$ & 0.011 & 0.001 \\
\hline 45 & Cyclotrisiloxane, hexamethyl- & $541-05-9$ & 0.0071 & 0.0062 \\
\hline 46 & Acetic acid, butyl ester & $123-86-4$ & 0.0033 & 0.0057 \\
\hline 47 & Nitric acid, butyl ester & $928-45-0$ & 0.030 & 0.014 \\
\hline 48 & Phenol & $108-95-2$ & 0.0021 & 0.0036 \\
\hline 49 & Cyclohexane, 1,1-dimethyl- & $590-66: 9$ & 0.0031 & 0.0027 \\
\hline 50 & 1-Hexanol & $111-27-3$ & 0.014 & 0.0036 \\
\hline 51 & 4-Heptanone & $123-19-3$ & 0.011 & 0.0031 \\
\hline 52 & Alkenol & & 0.014 & 0.002 \\
\hline 53 & 3-Heptanone & $106-35-4$ & 0.14 & 0.04 \\
\hline 54 & 3-Heptanol & $589-82-2$ & 0.037 & 0.012 \\
\hline 55 & Heptanal & $111-71-7$ & 0.0039 & 0.0033 \\
\hline
\end{tabular}


WHC-SD-WM-ER-449 REV. 1

\begin{tabular}{|c|c|c|c|c|}
\hline$\underset{\#}{C m p d}$ & Compound & $\begin{array}{l}\text { CAS' }^{1} \\
\text { Number }\end{array}$ & $\begin{array}{l}\text { Average }^{2} \\
\left(\mathrm{mg} / \mathrm{m}^{3}\right)\end{array}$ & $\begin{array}{l}\text { Standard } \\
\text { Deviation } \\
\left(\mathrm{mg} / \mathrm{m}^{3}\right) \\
\end{array}$ \\
\hline 56 & Cyclopent-2-ene-1-one, 2,3,4-trimethyl- & $83321-16-8$ & 0.0015 & 0.0026 \\
\hline 57 & Cyclobutanone, 3,3-dimethyl- & $1192-33-2$ & 0.0016 & 0.0027 \\
\hline 58 & 3-Heptanone, 6-methyl- & $624-42-0$ & 0.0050 & 0.0010 \\
\hline 59 & Nitric acid, pentyl ester & $1002-16-0$ & 0.012 & 0.006 \\
\hline 60 & 2,2'-Bioxepane & $74793-02-5^{\circ}$ & 0.0080 & 0.0071 \\
\hline 61 & 4-Hydroxy-4-methylpentanone & & 0.018 & 0.006 \\
\hline 62 & Pyridine, 2,4-dimethyl- & $108-47-4$ & 0.0013 & 0.0022 \\
\hline 63 & 3-Hepten-2-one, 4-methyl- & $22319-25-1$ & 0.040 & 0.016 \\
\hline 64 & Alkenol & & 0.018 & 0.005 \\
\hline 65 & 1-Heptanol & $111-70-6$ & 0.023 & 0.007 \\
\hline 66 & Cyclohexane, 1-ethyl-4-methyi-, trans- & $6236-88-0$ & 0.0014 & 0.0024 \\
\hline 67 & 2,2,4-Trimethyl-3-pentanone & $5857-36-3$ & 0.0040 & 0.0004 \\
\hline 68 & Octanal & $124-13-0$ & 0.0042 & 0.0036 \\
\hline 69 & Benzonitrile & $100-47-0$ & 0.0020 & 0.0034 \\
\hline 70 & Cyclopentane, (2-methylpropyl) & $3788-32-7$ & 0.024 & 0.012 \\
\hline 71 & Nitric acid, hexyl ester & $20633-11-8$ & 0.0084 & 0.0073 \\
\hline 72 & 1-Hexanol, 2-ethyl- & $104-76-7$ & 0.10 & 0.05 \\
\hline 73 & C3-Cyclohexane & & 0.0050 & 0.0044 \\
\hline 74 & Nitric acid, heptyl ester & $20633-12-9$ & 0.0032 & 0.0028 \\
\hline 75 & $\begin{array}{l}\text { 1H-Pyrozole, } 4,5 \text {-dihydro-1, } \\
\text { 5-dimethyl- and others }\end{array}$ & & 0.010 & 0.018 \\
\hline 76 & Alkane & & 0.024 & 0.018 \\
\hline 77 & 1-Propanol, 2,2-dimethyl-, nitrate & $926-42-1$ & 0.048 & 0.008 \\
\hline 78 & Nitric acid, hexyl ester & $20633-11-8$ & 0.0042 & 0.0036 \\
\hline 79 & 1-Octanol & $111-87-5$ & 0.021 & 0.010 \\
\hline 80 & Heptane, 2,2,4,6,6-pentamethyl- & $13475-82-6$ & 0.011 & 0.008 \\
\hline 81 & Acetophenone & $98-86-2$ & 0.026 & 0.019 \\
\hline 82 & Octanenitrile & $124-12-9$ & 0.022 & 0.015 \\
\hline 83 & 2-Nonanone & $821-55-6$ & 0.017 & 0.021 \\
\hline
\end{tabular}




\begin{tabular}{|c|c|c|c|c|}
\hline Cmpd & Compound & $\begin{array}{l}\text { CAS }^{1} \\
\text { Number }\end{array}$ & $\begin{array}{c}\text { Average }^{2} \\
\left(\mathrm{mg} / \mathrm{m}^{3}\right)\end{array}$ & $\begin{array}{l}\text { Standard } \\
\text { Deviation } \\
\left(\mathrm{mg} / \mathrm{m}^{3}\right)\end{array}$ \\
\hline 84 & Benzene, nitro- & $98-95-3$ & 0.010 & 0.009 \\
\hline $85^{\circ}$ & Nitric acid, hexyl ester & 20633-11-8 & 0.010 & 0.009 \\
\hline 86 & $\begin{array}{l}\text { Benzoic acid, 2-[(trimethylsilyl)oxy]-, } \\
\text { trimethylsilyl ester }\end{array}$ & $3789-85-3$ & 0.0033 & 0.0028 \\
\hline 87 & Heptane, 3-ethyl-5-methyl- & $52896-90-9$ & 0.0032 & 0.0028 \\
\hline 88 & Dodecane, 4-methyl- & $6117-97-1$ & 0.0039 & 0.0034 \\
\hline 89 & 1-Nonanol & $143-08-8$ & 0.0071 & 0.0061 \\
\hline 90 & Nonanenitrile & $2243-27-8$ & 0.0060 & 0.0052 \\
\hline 91 & C10-Alkanone & & 0.0073 & 0.0064 \\
\hline 92 & 2-Oxazolidinone, 5-methyl-3-(2-propenyl)- & $55956-20-2$ & 0.0014 & 0.0024 \\
\hline 93 & Nitric acid, decyl ester & $2050-78-4$ & 0.0058 & 0.0051 \\
\hline 94 & Decane, 2-methyl- . & $6975-98-0$ & 0.0047 & 0.0041 \\
\hline 95 & 1-Undecanol & $112-42-5$ & 0.0018 & 0.0031 \\
\hline 96 & Decanenitrile & $1975-78-6$ & 0.0047 & 0.0040 \\
\hline 97 & Decane, 5-ethyl-5-methyl- & $17312-74-2$ & 0.0066 & 0.0057 \\
\hline 98 & Tetradecane & $629-59-4$ & 0.020 & 0.018 \\
\hline 99 & Biphenyl & $92-52-4$ & 0.0029 & 0.0025 \\
\hline 100 & Pentadecane & $629-62-9$ & 0.0041 & 0.0036 \\
\hline 101 & Hexadecanoic acid & $57-10-3$ & 0.012 & 0.020 \\
\hline 102 & 1,1'-Biphenyl, 3-chloro- & $2051-61-8$ & 0.0047 & 0.0041 \\
\hline 103 & Diethyl Phthalate & $84-66-2$ & 0.020 & 0.007 \\
\hline 104 & 1,1'-Biphenyl, 3,3'-dichloro- & $2050-67-1$ & 0.0050 & 0.0044 \\
\hline 105 & Benzenesulfonamide, N-butyl- & $3622-84-2$ & 0.036 & 0.036 \\
\hline 106 & Isopropyl Palmitate & $142-91-6$ & 0.034 & 0.034 \\
\hline \multicolumn{2}{|c|}{ Sum of Tentatively Identified Compounds: } & & 2.6 & \\
\hline
\end{tabular}

$1 \mathrm{CAS}=$ Chemical Abstract Service.

2 Average of 3, 4-L TST samples, values listed are estimates. 
Table 4-8

Tank TX-118 Tentatively Identified Organic Compounds in TST Samples Sorted Alphanumerically Analyses Conducted by Oak Ridge National Laboratory

\begin{tabular}{|c|c|c|c|c|}
\hline$\underset{\#}{\text { Cmpd }}$ & Compound & $\begin{array}{l}\text { CAS }^{\dagger} \\
\text { Number }\end{array}$ & $\begin{array}{c}\text { Average }^{2} \\
\left(\mathrm{mg} / \mathrm{m}^{3}\right)\end{array}$ & $\begin{array}{l}\text { Standard } \\
\text { Deviation } \\
\left(\mathrm{mg} / \mathrm{m}^{3}\right) \\
\end{array}$ \\
\hline 77 & 1-Propanol, 2,2-dimethyl-, nitrate & $926-42-1$ & 0.048 & 0.008 \\
\hline 2 & 1-Propene, 2-methyl- & $115-11-7$ & 0.043 & 0.007 \\
\hline 38 & 1-Pentanol & $71-41-0$ & 0.022 & 0.005 \\
\hline 50 & 1-Hexanol & $111-27-3$ & 0.014 & 0.0036 \\
\hline 5 & 1-Propene, 2-methyl- & $115-11-7$ & 0.027 & 0.023 \\
\hline 16 & 1-Propanol & $71-23-8$ & 0.19 & 0.04 \\
\hline 42 & $1-$ Hexanol & $111-27-3$ & 0.0049 & 0.0084 \\
\hline 79 & 1-Octanol & $111-87-5$ & 0.021 & 0.010 \\
\hline 65 & 1-Heptanol & $111-70-6$ & 0.023 & 0.007 \\
\hline 72 & 1-Hexanol, 2-ethyl- & $104-76-7$ & 0.10 & 0.05 \\
\hline 95 & 1-Undecanol & $112-42-5$ & 0.0018 & 0.0031 \\
\hline 89 & 1-Nonanol & $143-08-8$ & 0.0071 & 0.0061 \\
\hline 102 & 1,1'-Biphenyl, 3-chloro- & $2051-61-8$ & 0.0047 & 0.0041 \\
\hline 104 & 1,1'-Biphenyl, 3,3'-dichloro- & $2050-67-1$ & 0.0050 & 0.0044 \\
\hline 75 & $\begin{array}{l}\text { 1H-Pyrozole, 4,5-dihydro-1, } \\
\text { 5-dimethyl- and others }\end{array}$ & & 0.010 & 0.018 \\
\hline 20 & 1H-Pyrazole, 1-methyl- & $930-36-9$ & 0.0022 & 0.0038 \\
\hline 92 & 2-Oxazolidinone, 5-methyl-3-(2-propenyl)- & $55956-20-2$ & 0.0014 & 0.0024 \\
\hline 18 & 2-Butanone & $78-93-3$ & 0.087 & 0.035 \\
\hline 40 & 2-Pentanone, 4,4-dimethyl- & $590-50-1$ & 0.020 & 0.002 \\
\hline 83 & 2-Nonanone & $821-55-6$ & 0.017 & 0.021 \\
\hline 14 & 2-Propanol, 2-methyl- & $75-65-0$ & 0.0054 & 0.0094 \\
\hline 13 & 2-Propenenitrile & $107-13-1$ & 0.0020 & 0.0040 \\
\hline 43 & $\begin{array}{l}\text { 2-Furanmethanol, tetrahydro-5-methyl-, } \\
\text { trans- }\end{array}$ & $54774-28-6$ & 0.0011 & 0.0019 \\
\hline 24 & 2-Butenal, (E)- & $123-73-9$ & 0.0064 & 0.0057 \\
\hline 25 & 2-B̈utanone, 3-methyl- & $563-80-4$ & 0.0024 & 0.0042 \\
\hline
\end{tabular}


WHC-SD-WM-ER-449 REV. 1

\begin{tabular}{|c|c|c|c|c|}
\hline Cmpd & Compound & $\begin{array}{l}\text { CAS }^{1} \\
\text { Number }\end{array}$ & $\begin{array}{c}\text { Average }{ }^{2} \\
\left(\mathrm{mg} / \mathrm{m}^{3}\right)\end{array}$ & $\begin{array}{l}\text { Standard } \\
\text { Deviation } \\
\left(\mathrm{mg} / \mathrm{m}^{3}\right)\end{array}$ \\
\hline 26 & 2-Butenenitrile & $4786-20-3$ & 0.0071 & 0.0004 \\
\hline 31 & 2-Heptene, (E)- & $14686-13-6$ & 0.0025 & 0.0043 \\
\hline 28 & 2-Heptene, $(E)-$ & $14686-13-6$ & 0.0047 & 0.0041 \\
\hline 30 & 2-Butanone, 3,3-dimethyl- & $75-97-8$ & 0.015 & 0.002 \\
\hline 60 & 2,2'-Bioxepané & $74793-02-5$ & 0.0080 & 0.0071 \\
\hline 67 & 2,2,4-Trimethyl-3-pentanone & $5857-36-3$ & 0.0040 & 0.0004 \\
\hline 63 & 3-Hepten-2-one, 4-methyl- & $22319-25-1$ & 0.040 & 0.016 \\
\hline 23 & 3-Butenenitrile & $109-75-1$ & 0.0046 & 0.0040 \\
\hline 27 & 3-Pentanone & $96-22-0$ & 0.011 & 0.010 \\
\hline 17 & 3-Buten-2-one & $78-94-4$ & 0.013 & 0.002 \\
\hline 53 & 3-Heptanone & $106-35-4$ & 0.14 & 0.04 \\
\hline 37 & 3-Pentanone, 2-methyl- & $565-69-5$ & 0.0024 & 0.0041 \\
\hline 41 & 3-Hexanone & $589-38-8$ & 0.0051 & 0.0013 \\
\hline 54 & 3-Heptanol & $589-82-2$ & 0.037 & 0.012 \\
\hline 58 & 3-Heptanone, 6-methyl- & $624-42-0$ & 0.0050 & 0.0010 \\
\hline 61 & 4-Hydroxy-4-methylpentanone & & 0.018 & 0.006 \\
\hline 51 & 4-Heptanone & $123-19-3$ & 0.011 & 0.0031 \\
\hline 46 & Acetic acid, butyl ester & $123-86-4$ & 0.0033 & 0.0057 \\
\hline 81 & Acetophenone & $98-86-2$ & 0.026 & 0.019 \\
\hline 76 & Alkane & & 0.024 & 0.018 \\
\hline 52 & Alkenol & & 0.014 & 0.002 \\
\hline 64 & Alkenol & & 0.018 & 0.005 \\
\hline 84 & Benzene, nitro- & $98-95-3$ & 0.010 & 0.009 \\
\hline 105 & Benzenesulfonamide, N-butyl- & $3622-84-2$ & 0.036 & 0.036 \\
\hline 86 & $\begin{array}{l}\text { Benzoic acid, } 2-[(\text { trimethylsilyl)oxy]-, } \\
\text { trimethylsilyl ester }\end{array}$ & $3789-85-3$ & 0.0033 & 0.0028 \\
\hline 69 & Benzonitrile & $100-47-0$ & 0.0020 & 0.0034 \\
\hline 99 & Biphenyl & $92-52-4$ & 0.0029 & 0.0025 \\
\hline 3 & Butane & $106-97-8$ & 0.034 & 0.016 \\
\hline
\end{tabular}


WHC-SD-WM-ER-449 REV. 1

\begin{tabular}{|c|c|c|c|c|}
\hline$\underset{\#}{\text { Cmpd }}$ & Compound & $\begin{array}{c}\text { CAS }^{1} \\
\text { Number }\end{array}$ & $\begin{array}{c}\text { Average }^{2} \\
\left(\mathrm{mg} / \mathrm{m}^{3}\right)\end{array}$ & $\begin{array}{l}\text { Standard } \\
\text { Deviation } \\
\left(\mathrm{mg} / \mathrm{m}^{3}\right)\end{array}$ \\
\hline 22 & Butane, 1-chloro- & $109-69-3$ & 0.0021 & 0.0037 \\
\hline 91 & C10-Alkanone & & 0.0073 & 0.0064 \\
\hline 73 & C3-Cyclohexane & & 0.0050 & 0.0044 \\
\hline 57 & Cyclobutanone, 3,3-dimethyl- & $1192-33-2$ & 0.0016 & 0.0027 \\
\hline 49 & Cyclohexane, 1,1-dimethyl- & $590-66-9$ & 0.0031 & 0.0027 \\
\hline 66 & Cyclohexane, 1-ethyl-4-methyl-, trans- & $6236-88-0$ & 0.0014 & 0.0024 \\
\hline 56 & Cyclopent-2-ene-1-one, 2,3,4-trimethyl- & $83321-16-8$ & 0.0015 & 0.0026 \\
\hline 70 & Cyclopentane, (2-methylpropyl)- & $3788-32-7$ & 0.024 & 0.012 \\
\hline 45 & Cyclotrisiloxane, hexamethyl- & $541-05-9$ & 0.0071 & 0.0062 \\
\hline 94 & Decane, 2-methyl- & $6975-98-0$ & 0.0047 & 0.0041 \\
\hline 97 & Decane, 5-ethyl-5-methyl- & $17312-74-2$ & 0.0066 & 0.0057 \\
\hline 96 & Decanenitrile & $1975-78-6$ & 0.0047 & 0.0040 \\
\hline 103 & Diethyl Phthalate & $84-66-2$ & 0.020 & 0.007 \\
\hline 88 & Dodecane, 4-methyl- & $6117-97-1$ & 0.0039 & 0.0034 \\
\hline 8 & Ethanol & $64-17-5$ & 0.18 & 0.05 \\
\hline 21 & Furan, tetrahydro- & $109-99-9$ & 0.024 & 0.003 \\
\hline 55 & Heptanal & $111-71-7$ & 0.0039 & 0.0033 \\
\hline 80 & Heptane, 2,2,4,6,6 pentamethyl- & $13475-82-6$ & 0.011 & 0.008 \\
\hline 87 & Heptane, 3-ethyl-5-methyl- & $52896-90-9$ & 0.0032 & 0.0028 \\
\hline 101 & Hexadecanoic acid & $57-10-3$ & 0.012 & 0.020 \\
\hline 11 & Isopropyl Alcohol & $67-63-0$ & 0.16 & 0.02 \\
\hline 106 & Isopropyl Paimitate & $142-91-6$ & 0.034 & 0.034 \\
\hline 7 & Methane, dichlorofluoro- & $75-43-4$ & 0.0020 & 0.0030 \\
\hline 1 & Methyl nitrite & $624-91-9$ & 0.034 & 0.048 \\
\hline 4 & Methyl Alcohol & $67-56-1$ & 0.39 & 0.10 \\
\hline 33 & Methyl Isobutyl Ketone & $108-10-1$ & 0.0059 & 0.0053 \\
\hline 15 & Nitric acid, ethyl ester & $625-58-1$ & 0.037 & 0.004 \\
\hline 20 & Nitric acid, propyl ester & $627-13-4$ & 0.025 & 0.005 \\
\hline 32 & Nitric acid, ethyl ester & $625-58-1$ & 0.028 & 0.006 \\
\hline
\end{tabular}




\begin{tabular}{|c|c|c|c|c|}
\hline Cmpd & Compound & $\begin{array}{l}\text { CAS }^{1} \\
\text { Number }\end{array}$ & $\begin{array}{l}\text { Average } 2 \\
\left(\mathrm{mg} / \mathrm{m}^{3}\right)\end{array}$ & $\begin{array}{c}\text { Standard } \\
\text { Deviation } \\
\left(\mathrm{mg} / \mathrm{m}^{3}\right)\end{array}$ \\
\hline 47 & Nitric acid, butyl ester & $928-45-0$ & 0.030 & 0.014 \\
\hline 59 & Nitric acid, pentyl ester & $1002-16=0$ & 0.012 & 0.006 \\
\hline 71 & Nitric acid, hexyl ester & 20633-11-8 & 0.0084 & 0.0073 \\
\hline 74 & Nitric acid, heptyl ester & $20633-12-9$ & 0.0032 & 0.0028 \\
\hline 78 & Nitric acid, hexyl ester & $20633-11-8$ & 0.0042 & 0.0036 \\
\hline 85 & Nitric acid, hexyl ester & $20633-11-8$ & 0.010 & 0.009 \\
\hline 93 & Nitric acid, decyl ester & $2050-78-4$ & 0.0058 & 0.0051 \\
\hline 6 & Nitrous acid, butyl ester & $544-16-1$ & 0.024 & 0.0003 \\
\hline 12 & Nitrous acid, butyl ester & $544-16-1$ & 0.012 & 0.001 \\
\hline 19 & Nitrous acid, butyl ester & $544-16-1$ & 0.028 & 0.005 \\
\hline 90 & Nonanenitrile & $2243-27-8$ & 0.0060 & 0.0052 \\
\hline 68 & Octanal & $124-13-0$ & 0.0042 & 0.0036 \\
\hline 39 & Octane, 2-chloro- & $628-61-5$ & 0.0016 & 0.0027 \\
\hline 82 & Octanenitrile & $124-12-9$ & 0.022 & 0.015 \\
\hline 100 & Pentadecane & $629-62-9$ & 0.0041 & 0.0036 \\
\hline 48 & Phenol & $108-95-2$ & 0.0021 & 0.0036 \\
\hline 36 & Propane, 2-methyl-2-nitro- & $594-70-7$ & 0.018 & 0.004 \\
\hline 34 & Propanoic acid & $79-09-4$ & 0.0046 & 0.0080 \\
\hline 35 & Pyrazine & $290-37-9$ & 0.0022 & 0.0038 \\
\hline 62 & Pyridine, 2,4-dimethyl- & $108-47-4$ & 0.0013 & 0.0022 \\
\hline 44 & Tetrachloroethylene & $127-18-4$ & 0.011 & 0.001 \\
\hline 98 & Tetradecane & $629-59-4$ & 0.020 & 0.018 \\
\hline 9 & Trichloromonofluoromethane & $75-69-4$ & 0.17 & 0.02 \\
\hline 10 & Trichloromonofluoromethane & $75-69-4$ & 0.013 & 0.023 \\
\hline \multicolumn{3}{|c|}{ Sum of Tentatively ldentified Compounds: } & 2.6 & \\
\hline
\end{tabular}

$1 \mathrm{CAS}=$ Chemical Abstract Service.

2 Average of 3, 4-L TST samples, values listed are estimates. 
Table 4-9

Tank TX-118 Tentatively ldentified Organic Compounds in TST Samples

Sorted by Estimated Concentration --

Analyses Conducted by Oak Ridge National Laboratory

\begin{tabular}{|c|c|c|c|c|}
\hline$\underset{\#}{C m p d}$ & Compound & $\begin{array}{l}\text { CAS }^{1} \\
\text { Number }\end{array}$ & $\begin{array}{c}\text { Average }^{2} \\
\left(\mathrm{mg} / \mathrm{m}^{3}\right)\end{array}$ & $\begin{array}{l}\text { Standard } \\
\text { Deviation } \\
\left(\mathrm{mg} / \mathrm{m}^{3}\right)\end{array}$ \\
\hline 4 & Methyl Alcohol & $67-56-1$ & 0.39 & 0.10 \\
\hline 16 & 1-Propanol & $71-23-8$ & 0.19 & 0.04 \\
\hline 8 & Ethanol & $64-17-5$ & 0.18 & 0.05 \\
\hline 9 & Trichloromonofluoromethane & $75-69-4$ & 0.17 & 0.02 \\
\hline 11 & Isopropyl Alcohol & $67-63-0$ & 0.16 & 0.02 \\
\hline 53 & 3-Heptanone & $106-35-4$ & 0.14 & 0.04 \\
\hline 72 & 1-Hexanol, 2-ethyl- & $104-76-7$ & 0.10 & 0.05 \\
\hline 18 & 2-Butanone & $78-93-3$ & 0.087 & 0.035 \\
\hline 77 & 1-Propanol, 2,2-dimethyl-, nitrate & $926-42-1$ & 0.048 & 0.008 \\
\hline 2 & 1-Propene, 2-methyl- & $115-11-7$ & 0.043 & 0.007 \\
\hline 63 & 3-Hepten-2-one, 4-methyl- & $22319-25-1$ & 0.040 & 0.016 \\
\hline 54 & 3-Heptanol & $589-82-2$ & 0.037 & 0.012 \\
\hline 15 & Nitric acid, ethyl ester & $625-58-1$ & 0.037 & 0.004 \\
\hline 105 & Benzenesulfonamide, N-butyl- & $3622-84-2$ & 0.036 & 0.036 \\
\hline 3 & Butane & $106-97-8$ & 0.034 & 0.016 \\
\hline 1 & Methyl nitrite & $624-91-9$ & 0.034 & 0.048 \\
\hline 106 & Isopropyl Palmitate & $142-91-6$ & 0.034 & 0.034 \\
\hline 47 & Nitric acid, butyl ester & $928-45-0$ & 0.030 & 0.014 \\
\hline 19 & Nitrous acid, butyl ester & $544-16-1$ & 0.028 & 0.005 \\
\hline 32 & Nitric acid, ethyl ester & $625-58-1$ & 0.028 & 0.006 \\
\hline 5 & 1-Propene, 2-methyl- & $115-11-7$ & 0.027 & 0.023 \\
\hline 81 & Acetophenone & $98-86-2$ & 0.026 & 0.019 \\
\hline 20 & Nitric acid, propyl ester & $627-13-4$ & 0.025 & 0.005 \\
\hline 70 & Cyclopentane, (2-methylpropyl)- & $3788-32-7$ & 0.024 & 0.012 \\
\hline 76 & Alkane & & 0.024 & 0.018 \\
\hline 6 & Nitrous acid, butyl ester & $544-16-1$ & 0.024 & 0.0003 \\
\hline 21 & Furan, tetrahydro- & $109-99-9$ & 0.024 & 0.003 \\
\hline
\end{tabular}




\begin{tabular}{|c|c|c|c|c|}
\hline$\underset{\#}{C}$ & Compound & $\begin{array}{l}\text { CAS }^{1} \\
\text { Number }\end{array}$ & $\begin{array}{c}\text { Average }^{2} \\
\left(\mathrm{mg} / \mathrm{m}^{3}\right)\end{array}$ & $\begin{array}{l}\text { Standard } \\
\text { Deviation } \\
\left(\mathrm{mg} / \mathrm{m}^{3}\right)\end{array}$ \\
\hline 65 & 1-Heptanol & $111-70-6$ & 0.023 & 0.007 \\
\hline 82 & Octanenitrile & $124-12-9$ & 0.022 & 0.015 \\
\hline 38 & 1-Pentanol & $71-41-0$ & 0.022 & 0.005 \\
\hline 79 & 1-Octanol & $111-87-5$ & 0.021 & 0.010 \\
\hline 103 & Diethyl Phthalate & $84-66-2$ & 0.020 & 0.007 \\
\hline 98 & Tetradecane & $629-59-4$ & 0.020 & 0.018 \\
\hline 40 & 2-Pentanone, 4,4-dimethyl- & $590-50-1$ & 0.020 & 0.002 \\
\hline 75 & $\begin{array}{l}\text { 1H-Pyrozole, } 4,5 \text {-dihydro-1, } \\
\text { 5-dimethyl- and others }\end{array}$ & & 0.010 & 0.018 \\
\hline 36 & Propane, 2-methyl-2-nitro- & $594-70-7$ & 0.018 & 0.004 \\
\hline 64 & Alkenol & & 0.018 & 0.005 \\
\hline 61 & 4-Hydroxy-4-methylpentanone & & 0.018 & 0.006 \\
\hline 83 & 2-Nonanone & $821-55-6$ & 0.017 & 0.021 \\
\hline 30 & 2-Butanone, 3,3-dimethyl- & $75-97-8$ & 0.015 & 0.002 \\
\hline 52 & Alkenol & & 0.014 & 0.002 \\
\hline 50 & 1-Hexanol & $111-27-3$ & 0.014 & 0.0036 \\
\hline 17 & 3-Buten-2-one & $78-94-4$ & 0.013 & 0.002 \\
\hline 10 & Trichloromonofluoromethane & $75-69-4$ & 0.013 & 0.023 \\
\hline 101 & Hexadecanoic acid & $57-10-3$ & 0.012 & 0.020 \\
\hline 12 & Nitrous acid, butyl ester & $544-16-1$ & 0.012 & 0.001 \\
\hline 59 & Nitric acid, pentyl ester & $1002-16-0$ & 0.012 & 0.006 \\
\hline 44 & Tetrachloroethylene & $127-18-4$ & 0.011 & 0.001 \\
\hline 80 & Heptane, 2,2,4,6,6-pentamethyl- & $13475-82-6$ & 0.011 & 0.008 \\
\hline 27 & 3-Pentanone & $96-22-0$ & 0.011 & 0.010 \\
\hline 51 & 4-Heptanone & $123-19-3$ & 0.011 & 0.0031 \\
\hline 84 & Benzene, nitro- & $98-95-3$ & 0.010 & 0.009 \\
\hline 85 & Nitric acid, hexyl ester & $20633-11-8$ & 0.010 & 0.009 \\
\hline 71 & Nitric acid, hexyl ester & $20633-11-8$ & 0.0084 & 0.0073 \\
\hline 60 & 2,2'-Bioxepane & $74793-02-5$ & 0.0080 & 0.0071 \\
\hline
\end{tabular}




\begin{tabular}{|c|c|c|c|c|}
\hline$\underset{\#}{\text { Cmpd }}$ & Compound & $\begin{array}{l}\text { CAS' }^{\prime} \\
\text { Number }\end{array}$ & $\begin{array}{c}\text { Average }^{2} \\
\left(\mathrm{mg} / \mathrm{m}^{3}\right)\end{array}$ & $\begin{array}{l}\text { Standard } \\
\text { Deviation } \\
\left(\mathrm{mg} / \mathrm{m}^{3}\right)\end{array}$ \\
\hline 91 & C10-Alkanone & & 0.0073 & 0.0064 \\
\hline 89 & 1-Nonanol & $143-08-8$ & 0.0071 & 0.0061 \\
\hline 26 & 2-Butenenitrile & $4786-20-3$ & 0.0071 & 0.0004 \\
\hline 45 & Cyclotrisiloxane, hexamethyl- & $541-05-9$ & 0.0071 & 0.0062 \\
\hline 97 & Decane, 5-ethyl-5-methyl- & $17312-74-2$ & 0.0066 & 0.0057 \\
\hline 24 & 2-Butenal, (E)- & $123-73-9$ & 0.0064 & 0.0057 \\
\hline 90 & Nonanenitrile & $2243-27-8$ & 0.0060 & 0.0052 \\
\hline 33 & Methyl Isobutyl Ketone & $108-10-1$ & 0.0059 & 0.0053 \\
\hline 93 & Nitric acid, decyl ester & $2050-78-4$ & 0.0058 & 0.0051 \\
\hline 14 & 2-Propanol, 2-methyl- & $75-65-0$ & 0.0054 & 0.0094 \\
\hline 41 & 3-Hexanone & $589-38-8$ & 0.0051 & 0.0013 \\
\hline 104 & 1,1'-Biphenyl, 3,3'-dichloro- & $2050-67-1$ & 0.0050 & 0.0044 \\
\hline 73 & C3-Cyclohexane & & 0.0050 & 0.0044 \\
\hline 58 & 3-Heptanone, 6-methyl- & $624-42-0$ & 0.0050 & 0.0010 \\
\hline 42 & 1-Hexanol & $111-27-3$ & 0.0049 & 0.0084 \\
\hline 96 & Decanenitrile & $1975-78-6$ & 0.0047 & 0.0040 \\
\hline 94 & Decane, 2-methyl- & $6975-98-0$ & 0.0047 & 0.0041 \\
\hline 28 & 2-Heptene, (E)- & $14686-13-6$ & 0.0047 & 0.0041 \\
\hline 102 & 1, t'-Biphenyl, 3-chloro- & 2051-61-8 & 0.0047 & 0.0041 \\
\hline 34 & Propanoic acid & $79-09-4$ & 0.0046 & 0.0080 \\
\hline 23 & 3-Butenenitrile & $109-75-1$ & 0.0046 & 0.0040 \\
\hline 68 & Octanal & $124-13-0$ & 0.0042 & 0.0036 \\
\hline 78 & Nitric acid, hexyl ester & $20633-11-8$ & 0.0042 & 0.0036 \\
\hline 100 & Pentadecane & $629-62-9$ & 0.0041 & 0.0036 \\
\hline 67 & 2,2,4-Trimethyl-3-pentanone & $5857-36-3$ & 0.0040 & 0.0004 \\
\hline 55 & Heptanal & $111-71-7$ & 0.0039 & 0.0033 \\
\hline 88 & Dodecane, 4-methyl- & $6117-97-1$ & 0.0039 & 0.0034 \\
\hline 46 & Acetic acid, butyl ester & $123-86-4$ & 0.0033 & 0.0057 \\
\hline
\end{tabular}


WHC-SD-WM-ER-449 REV. 1

\begin{tabular}{|c|c|c|c|c|}
\hline$\underset{\#}{\text { Cmpd }}$ & Compound & $\begin{array}{l}\text { CAS }^{1} \\
\text { Number }\end{array}$ & $\begin{array}{l}\text { Average }{ }^{2} \\
\left(\mathrm{mg} / \mathrm{m}^{3}\right)\end{array}$ & $\begin{array}{c}\text { Standard } \\
\text { Deviation } \\
\left(\mathrm{mg} / \mathrm{m}^{3}\right) \\
\end{array}$ \\
\hline 86 & $\begin{array}{l}\text { Benzoic acid, } 2-[(\text { trimethylsilyl)oxy]-, } \\
\text { trimethylsilyl ester }\end{array}$ & $3789-85-3$ & 0.0033 & 0.0028 \\
\hline 74 & Nitric acid, heptyl ester & $20633-12-9$ & 0.0032 & 0.0028 \\
\hline 87 & Heptane, 3-ethyl-5-methyl- & $52896-90-9$ & 0.0032 & 0.0028 \\
\hline 49 & Cyclohexane, 1,1-dimethyl- & $590-66-9$ & 0.0031 & 0.0027 \\
\hline 99 & Biphenyl & $92-52-4$ & 0.0029 & 0.0025 \\
\hline 31 & 2-Heptene, (E)- & $14686-13-6$ & 0.0025 & 0.0043 \\
\hline 25 & 2-Butanone, 3-methyl- & $563-80-4$ & 0.0024 & 0.0042 \\
\hline 37 & 3-Pentanone, 2-methyl- & $565-69-5$ & 0.0024 & 0.0041 \\
\hline 29 & 1H-Pyrazole, 1-methyl- & $930-36-9$ & 0.0022 & 0.0038 \\
\hline 35 & Pyrazine & $290-37-9$ & 0.0022 & 0.0038 \\
\hline 48 & Phenol & $108-95-2$ & 0.0021 & 0.0036 \\
\hline 22 & Butane, 1-chloro- & $109-69-3$ & 0.0021 & 0.0037 \\
\hline 69 & Benzonitrile & $100-47-0$ & 0.0020 & 0.0034 \\
\hline 7 & Methane, dichiorofluoro- & $75-43-4$ & 0.0020 & 0.0030 \\
\hline 13 & 2-Propenenitrile & $107-13-1$ & 0.0020 & 0.0040 \\
\hline 95 & 1-Undecanol & $112-42-5$ & 0.0018 & 0.0031 \\
\hline 39 & Octane, 2-chloro- & $628-61-5$ & 0.0016 & 0.0027 \\
\hline 57 & Cyclobutanone, 3,3-dimethyl- & $1192-33-2$ & 0.0016 & 0.0027 \\
\hline 56 & Cyclopent-2-ene-1-one, 2,3,4-trimethyl- & $83321-16-8$ & 0.0015 & 0.0026 \\
\hline 92 & 2-Oxazolidinone, 5-methyl-3-(2-propenyl)- & $55956-20-2$ & 0.0014 & 0.0024 \\
\hline 66 & Cyclohexane, 1-ethyl-4-methyl-, trans- & $6236-88-0$ & 0.0014 & 0.0024 \\
\hline 62 & Pyridine, 2,4-dimethyl- & $108-47-4$ & 0.0013 & 0.0022 \\
\hline 43 & $\begin{array}{l}\text { 2-Furanmethanol, tetrahydro-5-methyl-, } \\
\text { trans- }\end{array}$ & $54774-28-6$ & 0.0011 & 0.0019 \\
\hline Sum o & entatively Identified Compounds: & & 2.6 & \\
\hline
\end{tabular}

2 Average of 3, 4-L TST samples, values listed are estimates. 
